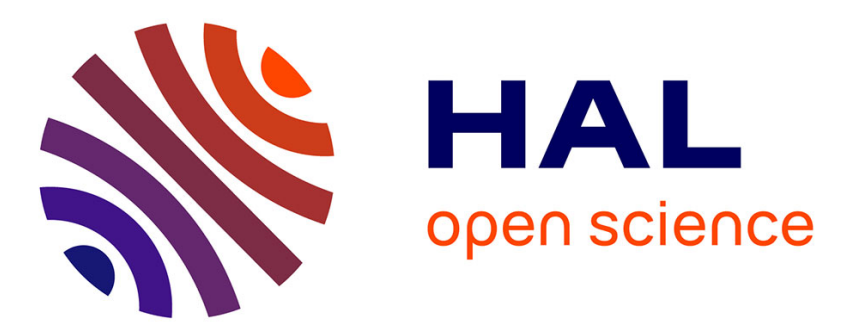

\title{
The diversity of Late Pleistocene and Holocene wild ungulates and kites structures in Armenia
}

Jwana Chahoud, Emmanuelle Vila, Adrian Bălăşescu, Rémy Crassard

\section{To cite this version:}

Jwana Chahoud, Emmanuelle Vila, Adrian Bălăşescu, Rémy Crassard. The diversity of Late Pleistocene and Holocene wild ungulates and kites structures in Armenia. Quaternary International, 2016, 395, pp.133-153. 10.1016/j.quaint.2015.04.024 . hal-01829334

\section{HAL Id: hal-01829334 \\ https://hal.science/hal-01829334}

Submitted on 4 Jul 2018

HAL is a multi-disciplinary open access archive for the deposit and dissemination of scientific research documents, whether they are published or not. The documents may come from teaching and research institutions in France or abroad, or from public or private research centers.
L'archive ouverte pluridisciplinaire HAL, est destinée au dépôt et à la diffusion de documents scientifiques de niveau recherche, publiés ou non, émanant des établissements d'enseignement et de recherche français ou étrangers, des laboratoires publics ou privés. 


\title{
The diversity of Late Pleistocene and Holocene wild ungulates and kites structures in Armenia
}

\author{
Jwana Chahoud a, b, *, Emmanuelle Vila a , Adrian Bălășescu ${ }^{c}$, Rémy Crassard ${ }^{\text {a }}$ \\ a CNRS, UMR 5133 Archéorient, Maison de l'Orient et de la Méditerranée, Lyon, France \\ ${ }^{\mathrm{b}}$ Natural History Museum, Lebanese University, Beirut, Lebanon \\ ${ }^{\mathrm{c}}$ National Museum of Romanian History, Calea Victoriei nr.12. Sector 3030026 Bucharest, Romania
}

\section{A R T I C L E I N F O}

\section{Article history:}

Available online 18 May 2015

\section{Keywords:}

Southern Caucasus

Biodiversity

Wild ungulates

Habitat range

Procurement strategy

Kites

\begin{abstract}
A B S T R A C T
Kites in Armenia were recently discovered, and investigations into their construction, typology and dating are ongoing. With these discoveries, it has become necessary to investigate a series of unsolved questions. In order to test the functions of kites, we conducted a synthesis describing the occurrence and habitat range of Late Pleistocene and Holocene wild ungulates in Armenia. Wildlife is discussed by emphasizing animal behavior and distribution, along with the hunting strategies adopted by the communities that inhabited Armenia.

In spite of the fact that wild ungulates did not contribute largely to the daily meat intake or to the major raw products needed by humans since their domestication (around $6000 \mathrm{cal}$. BC), wild goats, gazelle and red deer were the animals most frequently hunted in Armenia in different time periods and in a variety of landscapes. Hypotheses put forward suggest that these preferences might be linked to using kites as traps for herds at different seasons of the year and on different altitudes, between 3000 and $500 \mathrm{BC}$.
\end{abstract}

() 2015 Elsevier Ltd and INQUA. All rights reserved.

\section{Introduction}

Wildlife in Armenia varies across the different geographic landscapes and biotopes, between the valleys, mountains, forests, and plateaus of the country. A wide range of large mammals inhabited the Southern Caucasus, in particular aurochs (Bos primigenius), bison (Bison bonasus caucasicus), Caucasian tur (Capra caucasica), bezoar goat (Capra aegagrus), wild sheep (Ovis orientalis), roe deer (Capreolus capreolus), red deer (Cervus elaphus), elk (Alces alces), wild boar (Sus scrofa), wild horse (Equus ferus), onager (Equus hemionus) and gazelle (Gazella subgutturosa). In Armenia, animal habitat varied through time, both during the Pleistocene and the Holocene. Hunting activities were the focus of Paleolithic meat-based subsistence. Wild game such as Bison bonasus caucasicus and Capra caucasica were gradually replaced by species from husbandry and transhumance activities, a process beginning from the Neolithic onward (around $6000 \mathrm{cal}$. BC). From this period onwards, hunting was no longer the unique source of

\footnotetext{
* Corresponding author. CNRS, UMR 5133 Archéorient, Maison de l'Orient et de la Méditerranée, 7 Rue Raulin 69007, Lyon, France.

E-mail address: jwanachahoud@gmail.com (J. Chahoud).
}

meat, inducing a change in hunting strategies towards a focus on various biotopes and a wider spectrum of animals: caprines (sheep and goat), gazelle, cervids, equids, and bovines (Mezhlumyan, 1972; Chataigner, 1995; Bălăşescu et al., 2010; Pinhasi et al., 2011; Wilkinson et al., 2012; Berthon, 2014). The direct influence of the landscape played an important role in directing the hunting strategies of inhabitants, through the procurement of available resources from steppe regions (Gazella sp., Equus spp.), open areas (Bos primigenius, Equus spp.) and forested biotopes (Bison bonasus caucasicus, Cervus elaphus, Capreolus capreolus) (Vereshchagin, 1967; Chataigner, 1995; Chataigner et al., 2012).

Several concentrations of stone structures known as "desert kites" (or simply kites) have been recorded along mountain chains in the Mount Aragats region (Barge et al., 2013; Gasparyan et al., 2013; Brochier et al., 2014; Crassard et al., 2014). Kites are located in temperate semi-arid to arid areas in landscapes including plateaus, steppe, semi-deserts, and dwarf shrub vegetation. Recent studies in the Aragats massif have brought to light the architectural characteristics of kites: two or more long driving stone lines or antennae leading to a large surface enclosure, the latter regularly hidden in the landscape and with a funnel-shaped entrance, the enclosure being associated with several small closed circular rooms or cells around its periphery (Brochier et al., 2014). The ongoing 
excavations of kites in Armenia have yielded neither archaeological nor animal remains from kite structures. Lithic tools dated between the third and the first millennium $\mathrm{BC}$ have been recovered from the surface of certain kites in the northwestern fringes of the Ararat depression (Gasparyan et al., 2013). While hypotheses linking kites to hunting or husbandry were suggested for desert kites in the Middle East, kites in Armenia are mainly considered to be hunting structures (Gasparyan et al., 2013; Brochier et al., 2014). Even though kites are widely described as driving traps for gazelle herds, with the use of kite antennae as drive lines guiding animals towards the enclosures, no concrete evidence has of yet been recorded confirming this function (Échallier and Braemer, 1995; Legge and Rowley-Conwy, 2000; Holzer et al., 2010; Bar-Oz et al., 2011; Nadel et al., 2013; Zeder et al., 2013; Crassard et al., 2014; Chahoud et al., 2015). An analysis of the zooarchaeological record on hunting activities, along with reconstructing animal prehistoric occurrence and behavior in kite areas, are therefore needed in order to try testing the hunting hypothesis and the identification of the prey targeted by kite structures. Kites are mostly known from the observation of high-resolution satellite imagery, a technology that resulted in the increase of recorded kites to more than 4500 across the Middle East, Caucasus and Central Asia. Armenian examples were very recently discovered and represent an isolated concentration far from the Near Eastern ones to the South-West, and away from the Central Asian ones to the East (Barge et al., 2013; Crassard et al., 2014; a regularly updated interactive mapping of kite structures is available at http://www.globalkites.fr). This global zooarchaeological approach to better understand how kites were used and why they were built is innovative and will be applied in the near future to other regions where kites are highly concentrated (Chahoud et al., 2015). The Armenian case is therefore a first step to more comprehensive and global study of the kite phenomenon.

\section{Material and methods}

The preliminary dating of kites in Armenia has suggested a use of these structures between the Bronze and Iron Ages (third to first millennia BC) (Brochier et al., 2014). In this regard, kite distribution, as well as animal exploitation and occurrence, are analyzed with a special emphasis on the role of kites for hunting ungulates in Armenia. The available faunal studies from Armenia throughout the Late Pleistocene and the Holocene are not extensively detailed. Thirty-eight sites including 50 faunal assemblages are analyzed in this paper and cover the Middle Paleolithic, the Upper Paleolithic, the Mesolithic, the Neolithic, the Chalcolithic and the Bronze and Iron Ages periods of Armenia (Table 1).

Wild and domestic ungulates remains are recorded by their number of identified specimens (NISP). To prevent counting and inter-spectrum variability errors, only the ungulates are considered in the count of the total NISP (NISPu) including wild and domestic species. NISPw includes exclusively the number of identified specimens of wild animals. We noted the nature, chronology of sites, district, and faunal data from the literature, while each site location is shown on a Geographic Information System (GIS) that leads to producing thematic maps. In some cases the NISP of faunal remains is not presented, or is replaced by a minimal number of individuals (MNI) in the literature. Therefore, the species are marked as present $(\mathrm{P})$.

Meanwhile, several limitations are noted. First of all, zooarchaeological studies from the region are relatively rare. A number of sites cannot reflect the reality of wildlife exploitation, because of the low number of analyzed sites. Most of the recent faunal studies are preliminary, due to the ongoing state of archaeological excavation and analyses. The number of faunal assemblages is significantly different during various chronological periods (5 Paleolithic, 1 Mesolithic, 2 Neolithic, 7 Chalcolithic, 12 Early Bronze Age, 6 Middle Bronze Age, 10 Late Bronze Age and 7 Iron Age (Table 1, Fig. 1). Another problem lies in the absence of a clear standardized chronology from Armenian archaeological sites (Smith, 2005; Smith et al., 2009; Lindsay and Smith, 2006). We thus intended to keep a less granular division of chronological periods, which we divided into the Late Pleistocene (the Middle and Upper Paleolithic and the Mesolithic), Neolithic, Chalcolithic, Bronze Age and the Iron Age. From a methodological viewpoint, the total NISP of faunal assemblages is quite variable and could bias the results in the case of small assemblages. However, whether the latter are representative or not, they should be included in the analyses. We have chosen to include the small assemblages in order to have a greater overview of the region and to cover more geographic and chronological zones. The comparison between faunal assemblages was often conducted using the relative frequency or the percentage of NISP (Uerpmann, 1973; Grayson, 1979). Generally, the absence of homogeneous methods and published results of faunal assemblages highlights the problem of the identification of domestic or wild caprines, equids or bovines, a very delicate process indeed. The scarcity of fauna identified to a species level (e.g. Capra sp.: Capra aegagrus or Capra hircus?) is therefore the main reason explaining low NISP. Finally, the archaeological origin of assemblages also needs to be explored in a more balanced and detailed fashion. The diversity of ecosystems, environments, and landscapes of the distribution area of kites had a direct impact on hunting strategies. Therefore, the comparison between sites from the mountains, forest or steppe zones are subject to this bias. The nature of a site is another frequent source of error in such comparisons, as conservation of bone remains from caves, open-air camps, tombs or settlement areas is very variable. The comparison between the spectra of these sites could be biased by the difference of total NISP per site and in the degree of conservation of the bone (according to the nature of sites: settlement, graveyard, campsite, fortress; variable contexts: tomb, accumulation, deposit, floor ...). Moreover, details on spatial distribution of most of these faunal remains are not always made explicit in published reports.

Another aspect analyzed in this paper is the prehistoric and historical distribution in Armenia of wild animals. In order to establish the distribution of species over the complete territory of Armenia, we combined data from several references and elaborated historic and archaeozoological maps for each species. Archaeozoological records are based on available quantitative spectra from Armenian archaeological sites. When accurate quantitative data are not available, only presence or absence of species is recorded.

Historical data is defined by the range of habitats of species in historic times. In most cases the distinction between past and current distribution is not clear, due to the lack of updated records regarding the species' distribution. The current extent of species is integrated to the available data on extant animal range and current occurrence, according to the International Union for Conservation of Nature (IUCN, 2009). In some cases current species' distribution emphasizes the possible range of animal occurrence in an area, and not the actual observed distribution. References tend to combine historical records with fossils and archaeozoological data in order to establish the distribution area of several species. We kept these data under the banner "historical data", as there is no clear evidence or distinction of their occurrence in the archaeozoological spectrum, in the case of sites mentioned by Vereshchagin (1967). Data on species distribution is scarce, particularly with regards to range or area of occurrence (polygon on a map), while others are recorded as a localized observation in a distinct geographical position (point on a map). These issues introduce a slight error range 
Table 1

Archaeological sites mentioned in text.

\begin{tabular}{|c|c|c|c|c|c|}
\hline Period & Site & Context & District & Ref. archaeozoology & NISP \\
\hline \multirow[t]{3}{*}{ Middle Paleolithic } & Hovk-1 & Open air & Tavush & $\begin{array}{l}\text { Pinhasi et al., 2011, } \\
\text { Bar-Oz et al., } 2012\end{array}$ & 1214 \\
\hline & Kalavan-2 & Open air & Gegharkunik & Ghukasyan et al., 2011 & 129 \\
\hline & Lusarket (LKT1) & Cave & Aragatsotn & Adler et al., 2012 & 117 \\
\hline \multirow[t]{2}{*}{ Upper Paleolithic } & Kalavan-1 & Open air & Gegharkunik & $\begin{array}{l}\text { Chataigner et al., 2012, } \\
\text { Montoya et al., } 2013\end{array}$ & 28198 \\
\hline & Aghitu-3 & Cave & Siyunik & Kandel et al., 2014 & 256 \\
\hline Mesolithic & Kmlo-1 & Open air & Aragatsotn & Bălăşescu, 2010 & 4139 \\
\hline \multirow[t]{2}{*}{ Neolithic } & Aknashen-khaturnakh & Settlement & Armavir & $\begin{array}{l}\text { Badalyan et al., } 2010 \\
\text { Bălăşescu et al., } 2010\end{array}$ & 12810 \\
\hline & Aratashen & Settlement & Armavir & Badalyan et al., 2007 & 14957 \\
\hline \multirow[t]{8}{*}{ Chalcolithic } & Aknashen-khaturnakh & Settlement & Armavir & $\begin{array}{l}\text { Badalyan et al., } 2010, \\
\text { Bălășescu et al., } 2010\end{array}$ & 250 \\
\hline & Areni I & Cave & Vayots Dzor & Wilkinson et al., 2012 & 482 \\
\hline & Godedzor & Settlement & Siyunik & Bălăşescu, 2009; Chahoud, 2013 & 5889 \\
\hline & Horom I & Settlement & Shirak & Badalyan et al., 1994 & 12 \\
\hline & Ovçular tepesi & Settlement (pits) & Nakhichivan & Berthon et al., 2013 & 357 \\
\hline & Tekhut & Settlement & Armavir & Mezhlumyan, 1972 & 76 \\
\hline & Tsaghkunk (Mashtotsi Blur, Mkhl-tapa) & Settlement & Armavir & Mezhlumyan, 1972 & 174 \\
\hline & Tsaghahovit & Seasonal camp & Aragatsotn & Bălăşescu, 2008 & 13 \\
\hline \multirow[t]{12}{*}{ Early Bronze Age } & Anushavan & Settlement & Shirak & Badalyan and Avetisyan, 2007 & 91 \\
\hline & Garni & Settlement & Ararat & Mezhlumyan, 1972 & 123 \\
\hline & Gegharot & Settlement & Aragatsotn & Monahan, 2004 & 5635 \\
\hline & Karnut I & Settlement & Shirak & Badalyan and Avetisyan, 2007 & $\mathrm{P}$ \\
\hline & Keti I & Settlement & Shirak & Mezhlumyan, 1972 & $\mathrm{P}$ \\
\hline & Kosi Choter & Settlement & Lori & Mezhlumyan, 1972 & 94 \\
\hline & Metsamor & Settlement & Armavir & Mezhlumyan, 1972 & 2068 \\
\hline & Mokhrablur & Settlement & Armavir & Mezhlumyan, 1972 & 866 \\
\hline & Shengavit & Settlement & Yerevan & Mezhlumyan, 1972 & 3527 \\
\hline & Shirakavan & Settlement & Shirak & $\begin{array}{l}\text { Badalyan and Avetisyan, } 2007 \\
\text { Mirzoyan and Manaseryan, } 2009\end{array}$ & 145 \\
\hline & Takavoranist - Dimats[1] & Settlement & Lori & Mezhlumyan, 1972 & 56 \\
\hline & Talin & Burials & Aragatsotn & Badalyan and Avetisyan, 2007 & $\mathrm{P}$ \\
\hline \multirow[t]{6}{*}{ Middle Bronze Age } & Aparan II & Burials & Aragatsotn & Badalyan and Avetisyan, 2007 & 1 \\
\hline & Areni I & Cave & Vayots Dzor & Wilkinson et al., 2012 & 2 \\
\hline & Dzori Berd & Settlement & Aragatsotn & Sargsyan, 1988 & 1 \\
\hline & Metsamor & Burials & Armavir & Mezhlumyan, 1972 & 2153 \\
\hline & Sevan & Settlement & Gegharkunik & Mezhlumyan, 1972 & 429 \\
\hline & Shirakavan & Settlement & Shirak & Mirzoyan and Manaseryan, 2009 & 15 \\
\hline \multirow[t]{10}{*}{ Late Bronze Age } & Aparan II & Burials & Aragatsotn & Badalyan and Avetisyan, 2007 & $\mathrm{P}$ \\
\hline & Artik & Burials & Shirak & Badalyan and Avetisyan, 2007 & $\mathrm{P}$ \\
\hline & Gazanots & Burials & Aragatsotn & Badalyan and Avetisyan, 2007 & $P$ \\
\hline & Gegharot & Settlement & Aragatsotn & Monahan, 2004 & 3454 \\
\hline & Hnaberd & Burials & Aragatsotn & Monahan, 2004 & 1 \\
\hline & Jarjaris & Burials & Aragatsotn & Badalyan and Avetisyan, 2007 & 1 \\
\hline & Khojabagher & Burials & Aragatsotn & Badalyan and Avetisyan, 2007 & $\mathrm{P}$ \\
\hline & Kuchak & Burials & Aragatsotn & Badalyan and Avetisyan, 2007 & $\mathrm{P}$ \\
\hline & Kuchak & Settlement & Aragatsotn & Badalyan and Avetisyan, 2007 & $\mathrm{P}$ \\
\hline & Tsaghahovit & Settlement & Aragatsotn & Monahan, 2004 & 815 \\
\hline \multirow[t]{7}{*}{ Iron Age } & Erebuni Argishtikhnili Teishebaini & Settlement & Yerevan & Mirzoyan and Manaseryan, 2010 & 2330 \\
\hline & Godedzor & Settlement & Siyunik & Chahoud, 2013 & 492 \\
\hline & Keti I & Burials & Shirak & Mezhlumyan, 1972 & $\mathrm{P}$ \\
\hline & Mantash & Burials & Shirak & Badalyan and Avetisyan, 2007 & 25 \\
\hline & Shirakavan & Settlement & Shirak & Mirzoyan and Manaseryan, 2009 & 402 \\
\hline & Talin & Burials & Aragatsotn & Badalyan and Avetisyan, 2007 & 102 \\
\hline & Teishebaini & Settlement & Yerevan & cited in Vereshchagin, 1967:222 & 103 \\
\hline
\end{tabular}

in the accuracy in mapping the distribution of species. The animal occurrence in a region marked on the maps leads to an estimation of habitat range. These interpretations are the consequence of a systematic record from most recent observation and historical distribution data of species, analyzed in tandem with the available zoo-archaeological spectrum.

Armenian kites were recorded from the southwestern part of the country, an area limited to the Armavir and Aragatsotn districts (Fig. 2). The archaeological sites analyzed in this paper cover ten of eleven districts of Armenia ( 7 in Shirak, 2 in Lori, 1 in Tavush, 12 in Aragatsotn, 6 in Armavir, 3 in Yerevan, 1 in Ararat, 3 in Gegharkunik, 1 in Vayots Dzor and 2 in Siyunik; Table 1, Fig. 2). One site from Nakhichivan was analyzed (Ovcular Tepesi).

\section{Chronology of hunting activities in Armenia}

\subsection{Late Pleistocene: from the Middle Paleolithic to the end of Mesolithic (250,000-9000 BP)}

The hunting of wild ungulates was the principal source of meat during the Paleolithic in Armenia. The animal remains attested from archaeological sites dating to the late of Pleistocene cover the Middle Paleolithic (250,000-39,000 BP; 3 sites), the Upper Paleolithic (39,000-12,000 BP; 2 sites) and the Mesolithic periods (12,000-9000 BP; 1 site). The transition Middle and Upper Paleolithic is debated between 36 and $34 \mathrm{ka} \mathrm{BP}$ (Adler et al., 2006) and 39 ka BP (Pinhasi et al., 2011). 


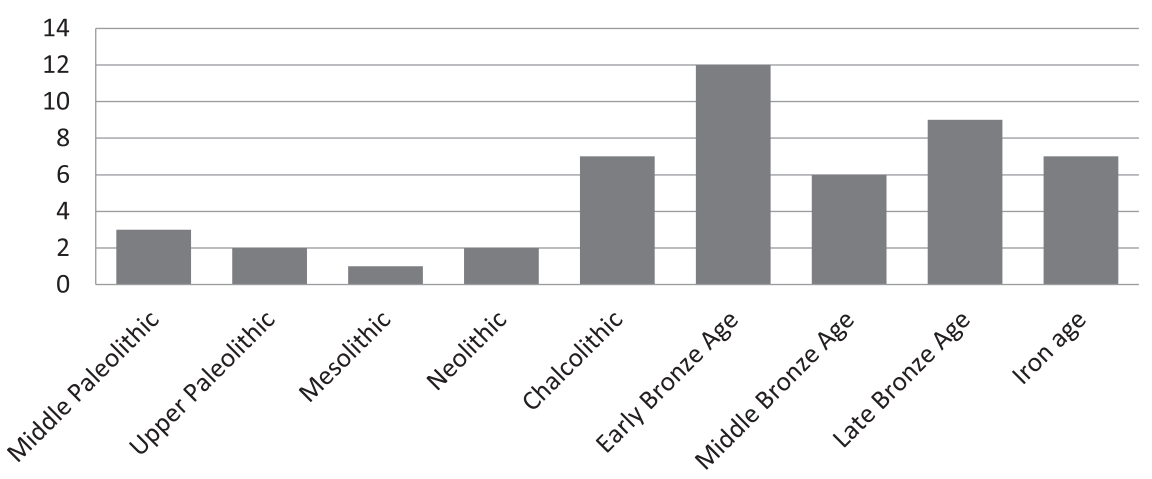

Fig. 1. Site distribution by chronological period (number of sites, Table 1).

The Middle Paleolithic sites are seasonal campsites located at high altitudes (Hovk-1:2040 m, Kalavan-2:1640 m, and Lusarket: $1400 \mathrm{~m}$ ) in the upper northwestern mountains of Armenia (Tavush district) and in the Hrazdan basalt (Aragatsotn district) (Fig. 3; Table 1). The NISPu from these sites is very limited and reveals hunting activities of wild ungulates, especially wild goats (cf. Capra aegagrus) and wild bovine (aurochs or bison). Other species were hunted at these sites, for instance roe deer and wild equid (Fig. 3). The exceptional diversity and large quantity of bones attested at Hovk-1 makes it unclear to what extent the faunal remains are related to man or to scavengers' activities. Those from Hovk-1 could reflect a natural accumulation of wild ungulates and carnivores. The high frequency of carnivores in the assemblage of Hovk-1 is due to a probable activity of natural



Fig. 2. Distribution of kites and districts in Armenia. 


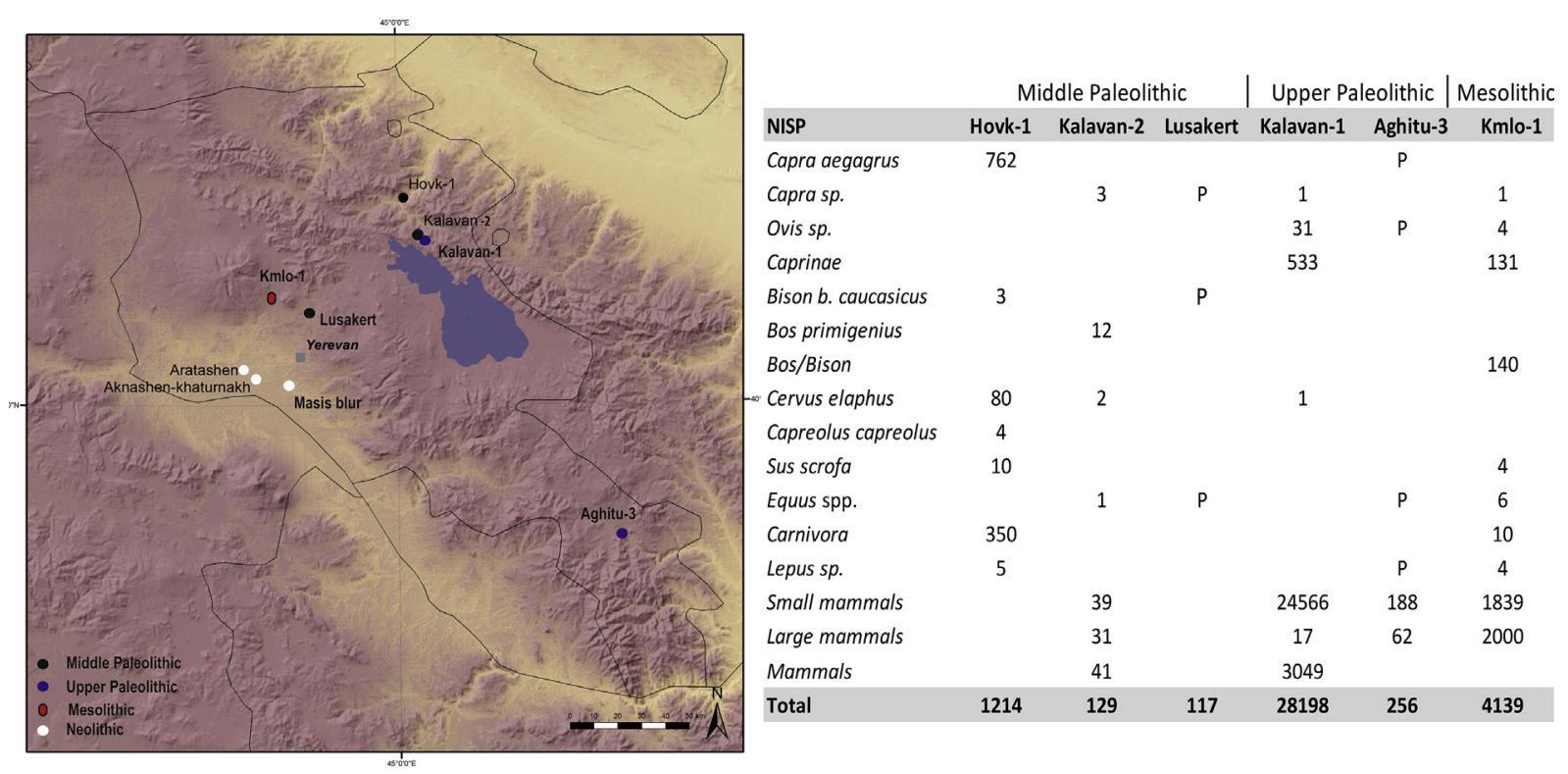

Fig. 3. Localization of archaeological sites and Late Pleistocene faunal spectrum (NISP).

deposition, where animals could have fallen and died on site in the earlier layers of the cave. The remains of bezoar goats observed at Hovk-1 reflect natural attritional mortality (Pinhasi et al., 2011).

Upper Paleolithic faunal remains are attested from an open-air site, Kalavan-1 in Northeastern Armenia (Gegharkunik) and at a cave site, Aghitu-3 in Southeastern Armenia (Siyunik) (Fig. 3; Table 1). These seasonal campsites are at a high altitude $(1640 \mathrm{~m})$. Bezoar goats and wild sheep are the major wild game identified. The spectrum comprises to a lesser extent red deer and wild horse. At Kalavan-1 the predominance of prime-aged goats could reflect specialized hunting activity (Chataigner et al., 2012; Montoya et al., 2013). The Aghitu-3 fauna is under study and listing of species is preliminary from the published data (Kandel et al., 2014).

The faunal spectrum during the Middle and Upper Paleolithic relates to the surrounding landscape and the preservation state of bones in cave and open-air sites. Nevertheless, specialized hunting dominates at the Upper Paleolithic site of Kalavan-1 with mainly one type of targeted prey: the wild goat (bezoar goat) and/or wild sheep (mouflon).

Meanwhile, in Georgia, hunting activities were mainly focused on migratory artiodactyls, especially the wild Caucasian tur (at high altitude sites) and/or bison/aurochs (at low altitude sites) during the Middle and Upper Paleolithic (Adler et al., 2006; Ghukasyan et al., 2011; Bar-Yosef et al., 2011; Bar Oz et al., 2012; Chataigner et al., 2012; Montoya et al., 2013). Similar strategies of specialized hunting focusing on one species have been discovered at a very few sites, essentially in caves (Nioradze and Otte, 2000; Adler et al., 2004, 2006; Meshveliani et al., 2004, 2007; Nioradze, 2006; BarOz et al., 2008, 2012). Trapping or driving techniques might have been used to hunt wild game on their routes of migration taking place from spring to autumn, a hypothesis proposed by Adler et al. (2006) and Chataigner et al. (2012).

The transition period between the Late Pleistocene and the Holocene in Armenia is poorly understood. The only site dated to the Mesolithic is the Kmlo-2 cave in the east of the Aragats massif. The fauna identified at this cave indicates a hunting activity focused on wild caprines (Capra sp. and Ovis sp.) and wild bovines (aurochs/ bison), and to a lesser extent on wild equids and roe deer (Bălăşescu, 2010), (Fig. 3).

\subsection{Neolithic (6000-5000 cal. BC)}

Three settlements are known dating to the Neolithic in Armenia. These are located in the district of Armavir: Aknashen, Aratashen and Masis Blur (Fig. 3). Ongoing faunal studies from Aknashen and Aratashen reveal an economy based mainly on caprine husbandry (mostly sheep), supplemented by cattle and swine breeding. Hunting activities were clearly on the decrease compared to earlier periods: 11\% (Aratashen) and 19\% (Aknashen) of NISPu (Figs. 3 and 4). The fauna from Masis Blur has not yet been published (Martirosyan-Olshansky et al., 2013).

A wide range of animals is attested at Aknashen and at Aratashen. Nevertheless, red deer is the most frequent game at Aratashen ( $10 \%$ of NISPu, $90 \%$ of NISPw), whereas at Aknashen gazelle exploitation (6\% NISPu, 33\% NISPw) became as important as red deer (8\% NISPu, 45\% NISPw). Along with the preferred preys, deer and gazelle, other less frequent species were hunted: wild boar, aurochs, equids, and roe deer. Wild goat and wild sheep are present in the spectrum, yet in sporadic quantities (Badalyan et al., 2010; Bălășescu et al., 2010; Vila et al., 2015) (Fig. 4, Table 2).

\subsection{Chalcolithic (5000-3500 cal. BC)}

After the Neolithic and the time of incipient domestication, husbandry became the main focus of the subsistence economy of prehistoric societies in the southern Caucasus. Yet as late as the 5th-4th millennium BC the Chalcolithic communities included livestock rearing and hunting activities in their way of life. This latter activity predominated in western Georgia and to a lesser extent in Armenia, though there may be a bias because of the lack of excavated sites (Chataigner, 1995:218; Kiguradze and Sagona, 2003:40; Piro, 2008: 25).

The analysis of seven zooarchaeological assemblages lead to the identification of several forms of hunting practices, which matched different ecological zones (steppe, mountain, forest and open regions). Faunal assemblages studies are rare (7 in Armenia and 1 in Nakhichivan), and the total NISPu from seven sites is not relevant $(<600 \mathrm{NISP})$ and might not be representative of the reality of animal exploitation during this period (Fig. 5, Tables 1 and 3 ). 


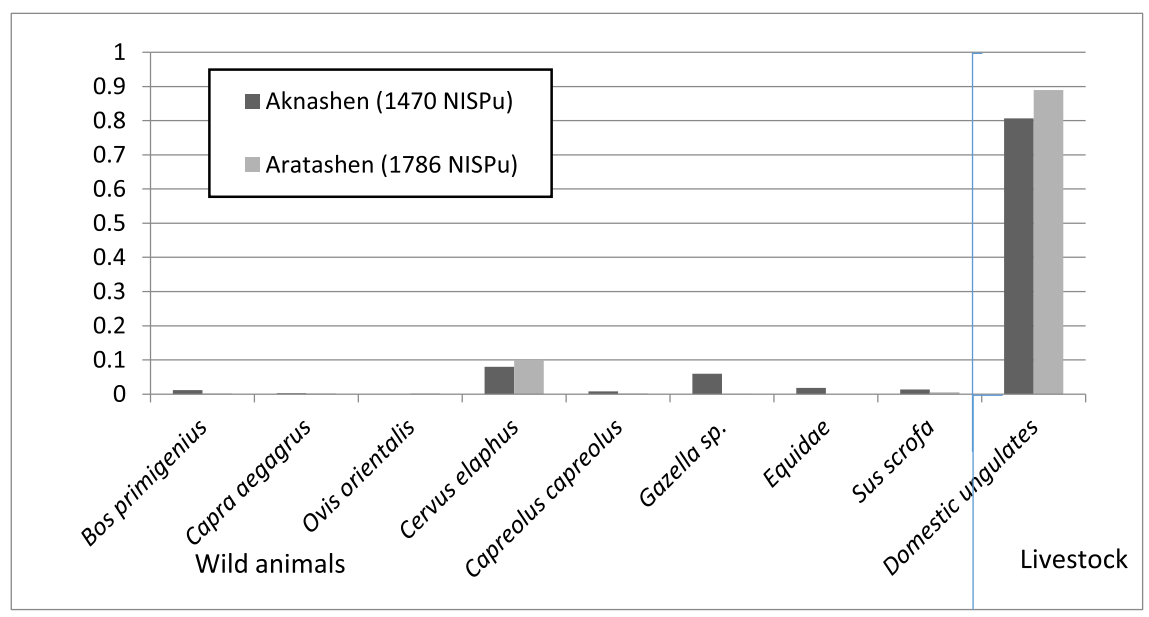

Fig. 4. Frequency of ungulates from Neolithic sites, Armenia (\% NISPu, Table 2).

The most common wild animals in most Chalcolithic settlements include red deer, wild goats, and wild boar. Roe deer, aurochs, bison, gazelle, and wild sheep are less recurring. Wild animals represent less than $10 \%$ of the total NISPu at all Chalcolithic sites of Armenia. The wild goats are an exception at Tsaghkunk (Armavir), possibly related to sample size (only 112 NISP; Mezhlumyan, 1972). The assemblages from Horom (Shirak) and Areni (Vayots Dzor) are also limited in number of specimens (Badalyan et al., 1994; Wilkinson et al., 2012, Table 3).

Clearly, the faunal assemblages from different sites are not comparable, due to the disparity of total NISP and of methods of identification. Aknashen and Godedzor display significant difference from other assemblages, which can be a result of ongoing studies (Bălășescu, 2009; Bălășescu et al., 2010; Chahoud, 2013). Hence, forthcoming interpretations are subject to further investigation in order to enlarge the Chalcolithic sample with recent faunal studies. In addition, Ovçular Tepesi, a Chalcolithic site from Nakhichivan, has revealed rare hunting activities, focused mainly of roe deer (Berthon et al., 2013).

The distribution of wild animals consumed or exploited at Chalcolithic sites reveals the impact of the local environment on hunting strategies. Sites like Aknashen, Tsaghkunk and Tekhut located in the Ararat district and Godedzor in Siyunik show diversity in wild game, with bezoar goats, red deer and boars dominating the spectrum. Nevertheless, aurochs and bison are attested in Tsaghahovit and Godedzor (Bălășescu, 2008, 2009). Gazelles are found so far at Aknashen only (Bălășescu et al., 2010,

Table 2

Ungulates spectrum, Neolithic, Armenia (NISPu).

\begin{tabular}{llrr}
\hline & NISPu & Aknashen-khaturnakh & Aratashen \\
\hline \multirow{2}{*}{ Wild } & Bos primigenius & 17 & 2 \\
& Capra aegagrus & 3 & 3 \\
& Ovis orientalis & & 2 \\
& Cervus elaphus & 118 & 178 \\
& Capreolus capreolus & 12 & 2 \\
& Gazella subgutturosa & 87 & 1 \\
& Equidae & 27 & \\
Livestock & 20 & 9 \\
& Sus scrofa & 761 & 380 \\
& Bos taurus & 83 & 248 \\
& Capra hircus & 335 & 909 \\
& Ovis aries & 7 & 52 \\
& Sus scrofa dom. & 27 & 2892 \\
& Bovinae & 3946 & $\mathbf{4 6 7 8}$ \\
\hline & Caprinae & 36 &
\end{tabular}

Fig. 5). A special case was observed at Tsaghkahovit in the north Aragats massif, despite the low number of identified specimens (13 of 219 remains). It was a hunting campsite where wild ungulates were the main genus attested - particularly wild equids (Bălăşescu, 2008). Moreover, these wild equids were rarely identified at other Chalcolithic sites (Tekhut and Aknashen in Armavir; Table 3).

Multiple biotopes are suggested by the presence of this wild game. The inhabitants of these sites hunted wild goats from the mountains and slopes, red and roe deer and boar from forested zones; aurochs, bison, horse and onager from open landscapes; and gazelle and equids from steppe and arid ecosystems. With regards to the frequency of species, we notice that, along with the domestic livestock dominating the diet, wild goat and red deer were the most common prey (Fig. 5). Further investigation is needed to clarify whether these preferences were dictated by resource procurement or by cultural choices.

\subsection{Early Bronze Age (3500-2200 cal. BC)}

In the Early Bronze Age (EBA), animal husbandry tended to be specialized, with widespread transhumance and activities related to nomadism (Sagona, 1993; Palumbi, 2003; Frangipane and Palumbi, 2007; Piro, 2008). Hunting did not play a major role in the subsistence economy.

Twelve EBA sites were analyzed (Fig. 6, Tables 1 and 4). All faunal remains come from settlement areas, while one in Talin (Aragatsotn) comes from a burial context. EBA faunal assemblages are sporadic (Tables 1 and 4). They were studied applying different archaeo-zoological methods, omitting any discussion of species identification, and therefore might not be accurately representative of animal exploitation at that period (for discussion on rare faunal studies from EBA Transcaucasia: see e.g. Piro, 2008).

Wild animals are very limited in the EBA spectrum (Table 4). Considering all the assemblages as one, less than $3 \%$ of wildlife is ungulates (Fig. 7). The main species hunted during the EBA was red deer. Wild goats are less important than in the earlier periods but represent a good proportion in the total percentage of prey after red deer, especially at Garni and Shengavit in the Ararat district (Fig. 6). The hunting activities during the EBA tend to be exclusively focused on red deer, with very irregular frequencies of roe deer (Garni, Shengavit, Keti 1, Kosi Choter and Shirakavan), wild boar (Kosi Choter at Lori), gazelle (Ghegharot in Aragatsotn and Shirakavan in Shirak) (Figs. 6 and 7, Table 4). The presence of camelid and buffalo bones is suspected at Shirakavan (Shirak) and at Kosi Choter (Lori), respectively (Table 4). 


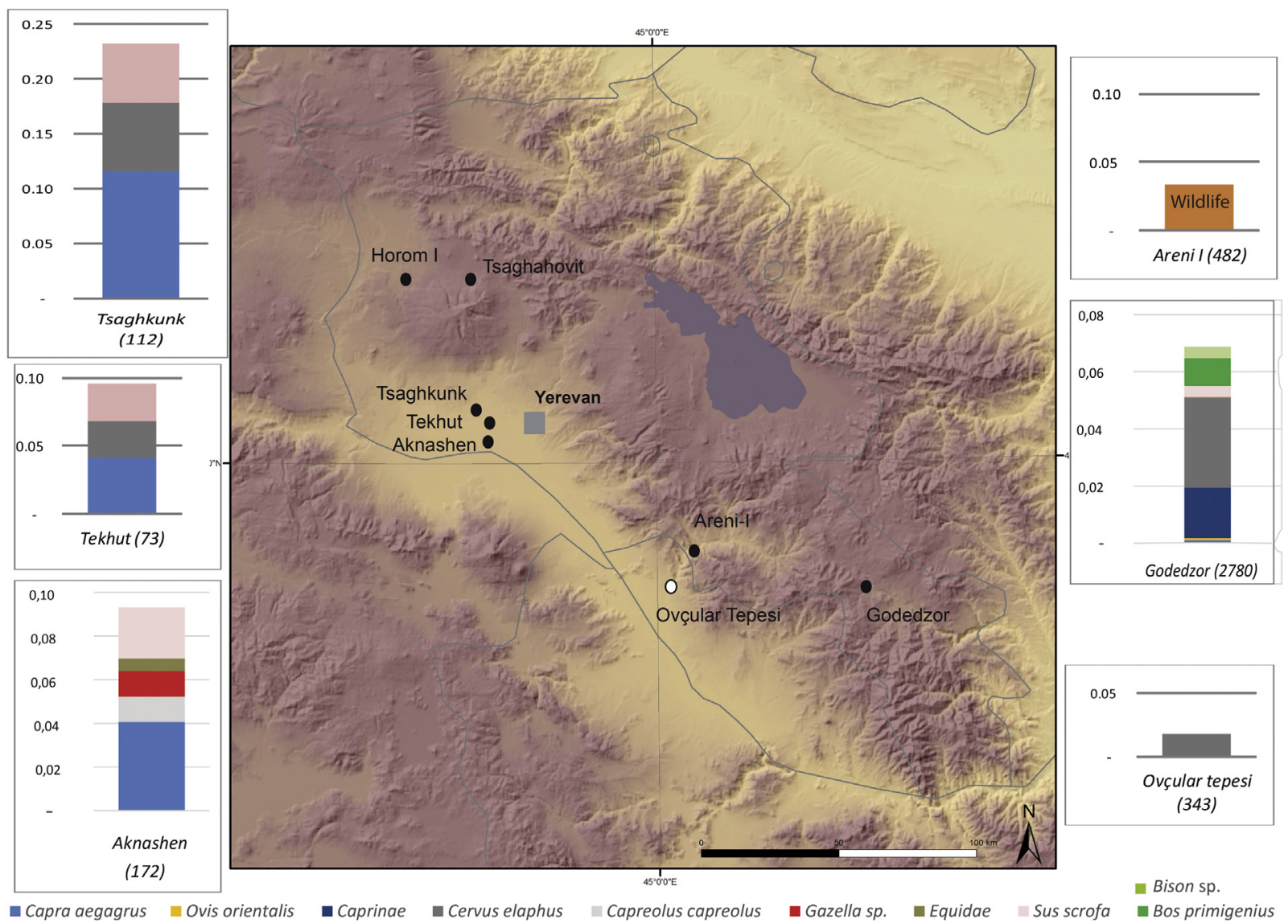

Fig. 5. Wild ungulate distribution and relative frequency, Chalcolithic, Armenia (NISPu, Ovcular Tepesi in Nakhichivan Table 3).

In the case of the EBA strata, attribution of domestic or wild horse and equids to onagers cannot be clearly deduced from the data. Equids are therefore not considered wild game. Centers of horse domestication have not been definitely identified. One location for domestication was pinpointed with certainty in the western part of the Eurasian Steppe. This process of domestication appears to have occurred approximately 6000 years ago (Warmuth et al., 2012). However, evidence of domesticated horses was also found in northern Khazakstan (Outram et al., 2009). By contrast, the appearance of domestic horses in Armenia is still not clearly dated. The identification of wild ass or onagers is awkward, as the former species are often confused with other equids. Its degree of distribution among Armenian wild fauna therefore remains an unresolved issue (occurrences mentioned by Crees and Turvey (2014) are based on references from literature and unpublished data).

\subsection{Middle Bronze Age (2200-1500 cal. BC)}

Records of faunal remains are attested from five settlements and one burial site dated to the Middle Bronze Age (MBA). Two sites, Metsamor and Sevan, show a detailed spectrum (Mezhlumyan, 1972, Fig. 8). According to available data, hunting activities were carried out, but the main focus was on nomadic pastoralism and husbandry. When wild game is attested, only at two MB sites (Metsamor at Armavir and Shirakavan at Shirak), red deer, wild

Table 3

Wild ungulates spectrum, Chalcolithic, Armenia (NISPu).

\begin{tabular}{|c|c|c|c|c|c|c|c|c|c|}
\hline & NISPu & Aknashen & Areni I & Godedzor & Horom I & Ovçular tepesi & Tekhut & Tsaghkunk & Tsaghahovit \\
\hline \multirow[t]{12}{*}{ Wild } & Capra aegagrus & 7 & & 3 & & & 3 & 13 & \\
\hline & Ovis orientalis & & & 2 & & & & & \\
\hline & Caprinae & & & 49 & & & & & \\
\hline & Cervus elaphus & & & 87 & & 6 & 2 & 7 & \\
\hline & Capreolus capreolus & 2 & & & & & & & \\
\hline & Gazella subgutturosa & 2 & & & & & & & \\
\hline & Equidae & 1 & & 1 & & & 19 & & 10 \\
\hline & Bos primigenius & & & 27 & & & & & \\
\hline & Bison sp. & & & 11 & & & & & \\
\hline & Bos/Bison & & & & & & & & 2 \\
\hline & Sus scrofa & 4 & & 11 & & & 2 & 6 & 1 \\
\hline & Wildlife & & 16 & & & & & & \\
\hline \multirow[t]{2}{*}{ Livestock } & & 156 & 466 & 2589 & 1 & 337 & 47 & 86 & \\
\hline & Total & 172 & 482 & 2780 & 12 & 343 & 73 & 112 & 13 \\
\hline
\end{tabular}




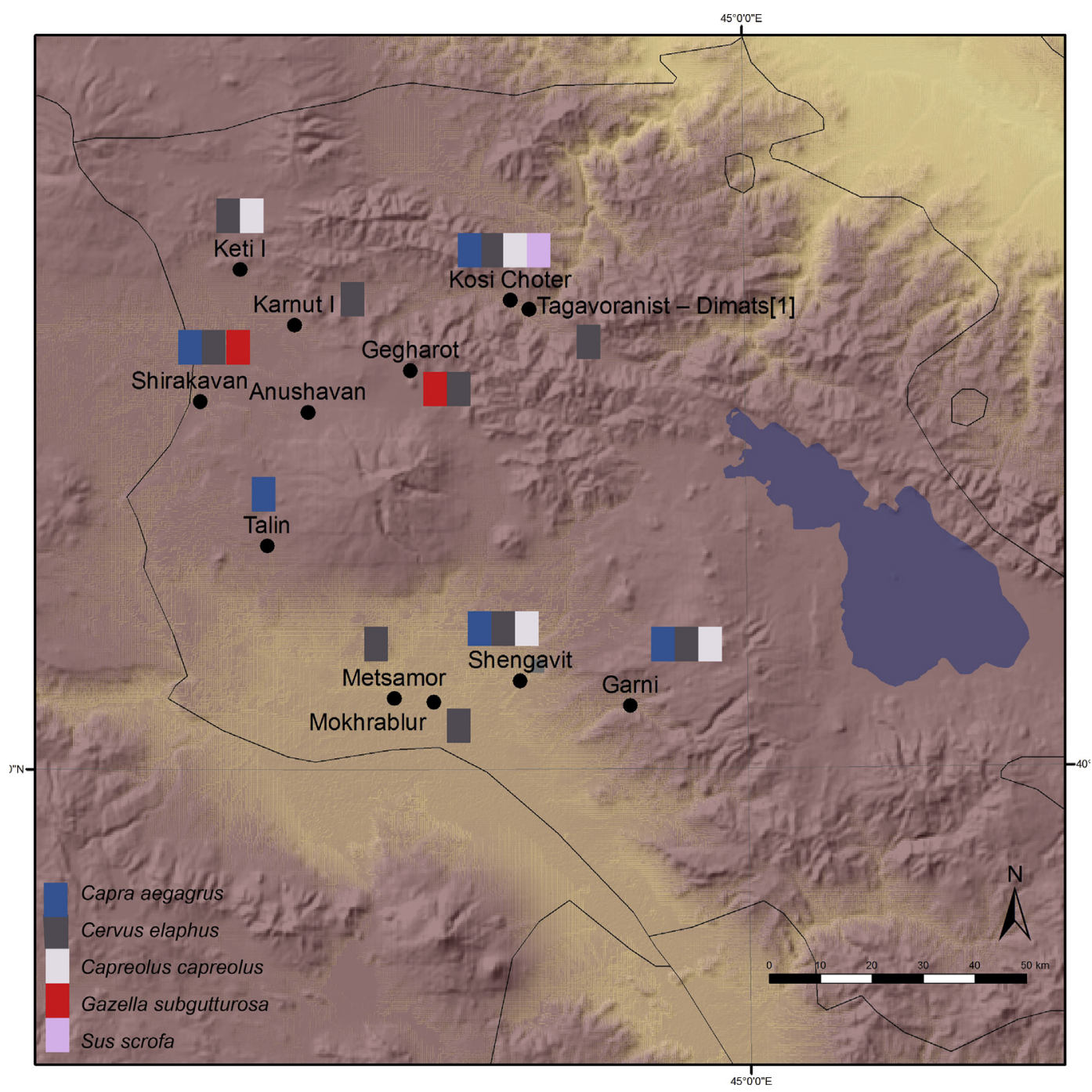

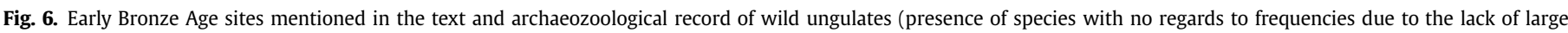
samples of NISP).

goat, boar and gazelle are the hunted species (Mezhlumyan, 1972; Mirzoyan and Manaseryan, 2009, Fig. 8).

\subsection{Late Bronze Age (1500-1200 cal. BC)}

Nine sites from the Armenian Late Bronze Age (LBA) were analyzed (Table 1, Fig. 9). Faunal remains were collected from burial contexts at Aparan II, Artik, Gazanots, Hnaberdm Jarjaris,
Khojabagher and Kuchak, and from three settlement sites: Gegharot, Kuchak and Tsaghahovit (Fig. 9).

Recording the presence of wild animals from burial contexts does not reflect the real contribution of hunting activities to the diet, nor does it reflect the diversity of wild game hunted in this region. The range of wild game from these contexts is therefore interpreted with caution. Wild animal bones were recorded only from the Aragatsotn district, at two settlement sites (Gegharot and

Table 4

Wild ungulate spectrum, Early Bronze Age, Armenia (NISPu; (Equid domestic and/or wild)).

\begin{tabular}{|c|c|c|c|c|c|c|c|c|c|c|}
\hline Taxon & Capra aegagrus & Cervus elaphus & Cervidae & Capreolus capreolus & Gazella subgutturosa & Bubalus sp. & Sus scrofa & Equus spp. & Camelidae & NISPu total \\
\hline Anushavan & & & & & & & & 2 & & 88 \\
\hline Garni & 10 & 17 & & 2 & & & & 7 & & 106 \\
\hline Gegharot & & 11 & & & 1 & & & 2 & & 688 \\
\hline Metsamor & & 9 & & & & & & 310 & & 2032 \\
\hline Mokhrablur & & 3 & & & & & & 27 & & 860 \\
\hline Shengavit & 17 & 121 & & 21 & & & & 472 & & 3041 \\
\hline Takavoranist & & 7 & & & & & & 11 & & 52 \\
\hline Karnut I & & & $\mathrm{P}$ & & & & & $\mathrm{P}$ & & $\mathbf{P}$ \\
\hline Keti I & & $\mathrm{P}$ & & $P$ & & & & & & $\mathbf{P}$ \\
\hline Kosi Choter & $\mathrm{P}$ & 10 & & 7 & & $\mathrm{P}$ & 9 & 37 & & 93 \\
\hline Shirakavan & & 9 & & 2 & $\mathrm{P}$ & & & 33 & 1 & 123 \\
\hline Talin & $\mathrm{P}$ & & & & & & & $\mathrm{P}$ & & $\mathbf{P}$ \\
\hline
\end{tabular}




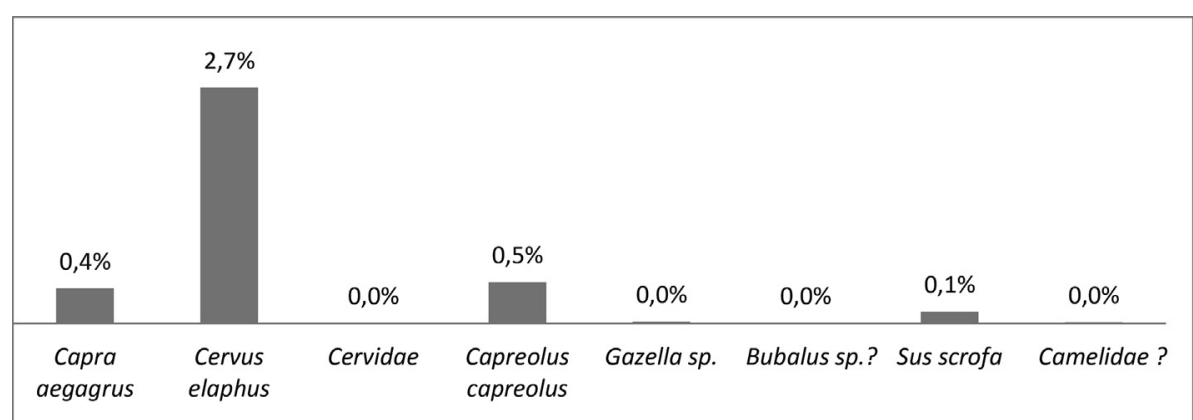

Fig. 7. Frequency of wild ungulates from the total sum NISPu of Early Bronze Age sites, Armenia (\%NISPu, total NISPu: 7090, Table 4).



Fig. 8. Wild ungulate remains from the Middle Bronze Age sites, Armenia. 


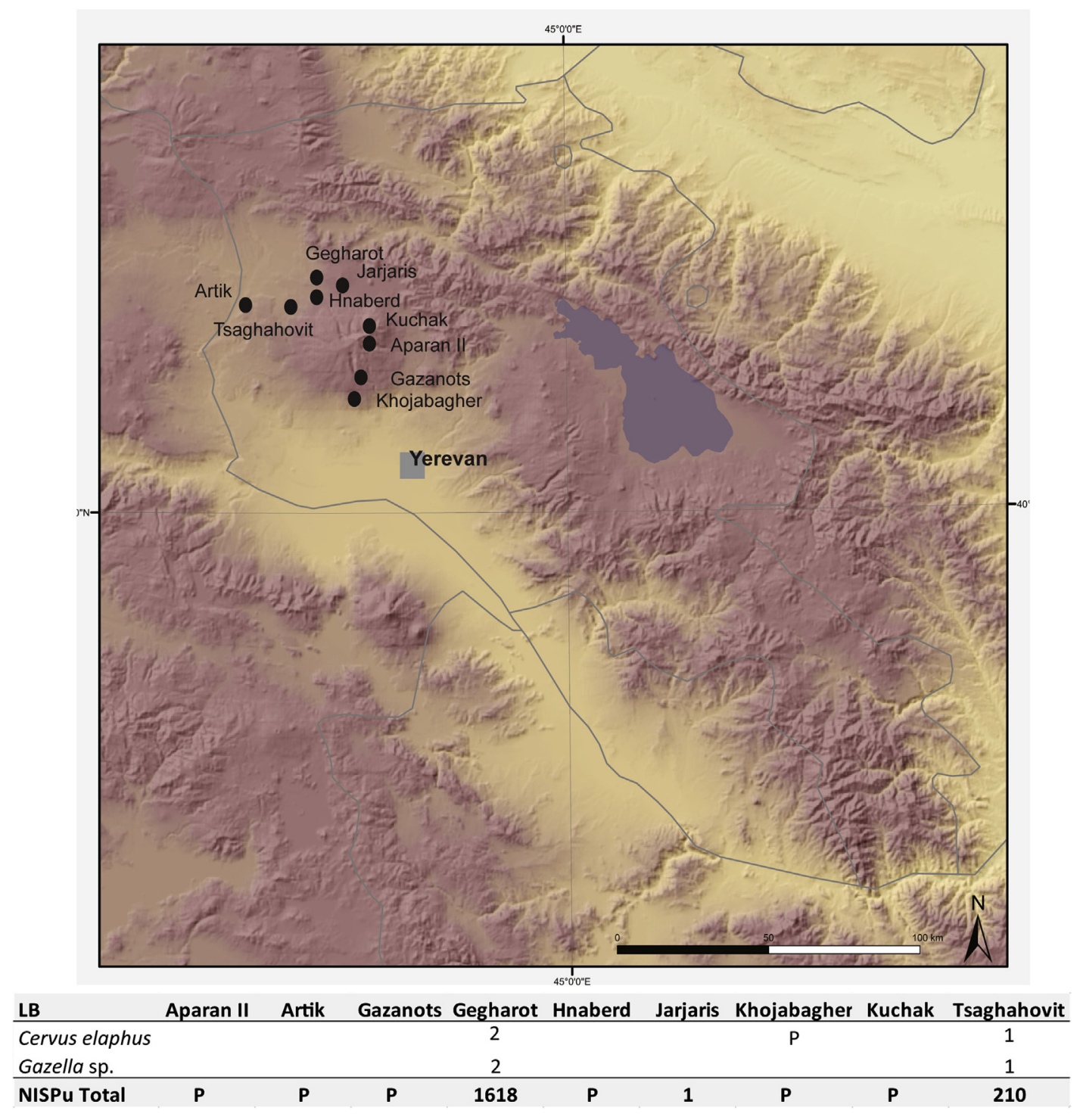

Fig. 9. Wild ungulate remains from the Late Bronze Age sites, Armenia.

Tsaghahovit), and were mentioned as grave goods in the burial context of Khojabagher (Monahan et al., 2004, 2004, 2008; Badalyan and Avetisyan, 2007, Fig. 9). The main wild species attested during the LBA are red deer and gazelle (Fig. 9).

\subsection{Iron Age (1200-500 cal. BC)}

Seven sites have yielded animal bones (Table 1). Three faunal assemblages from burial contexts (Keti-1, Mantash and Talin) provided domestic animal remains. The other four sites are interpreted as settlements, and had remains of wild animals. The spectra of
Erebuni, Argishtikhnili and recent studies from Teishebaini in the Yerevan district are grouped together as given in the publication by the authors (Mirzoyan and Manaseryan, 2010).

Theses Iron Age assemblages indicate that husbandry and livestock rearing were practiced on a very large scale in Armenia during the Iron Age (including the Urartian period). Hunting became an elite activity. Wild game represents between $2 \%$ and $13 \%$ of the NISPu. The major attested species are red deer. Gazelle are relatively important as their remains were attested at four sites. Other prey is recorded to a lesser extent: wild goats and sheep and roe deer (Table 5; Fig. 10).

Table 5

Wild ungulate spectrum, NISPu, Iron Age, Armenia (Equid domestic and/or wild).

\begin{tabular}{|c|c|c|c|c|c|c|c|}
\hline & Capra aegagrus & Ovis orientalis & Cervus elaphus & Capreolus capreolus & Gazella subgutturosa & Equus spp. & NISPu total \\
\hline Erebuni, Argishtikhnili, Teishebaini & & 5 & 21 & 2 & 8 & 83 & 1514 \\
\hline Godedzor & & & 33 & & 5 & & 371 \\
\hline Keti I & & & & & & $\mathrm{P}$ & $\mathbf{P}$ \\
\hline Mantash & & & & & & 1 & 1 \\
\hline Shirakavan & & & 46 & 1 & 4 & 56 & 137 \\
\hline Talin & & & & & & $\mathrm{P}$ & $\mathbf{P}$ \\
\hline Teishebaini & 1 & 1 & 4 & & 2 & 14 & 22 \\
\hline
\end{tabular}






Fig. 10. Relative frequency of wild ungulates at Iron Age sites in Armenia (NISPu, Table 5).

\section{Evidence for the use of kites?}

The function of kites is discussed by combining the available data of animal exploitation, animal ethology, archaeological analyses of kites and ethnographical and rock art evidence in Armenia. In order to test the hypothesis surmising that kite structures were used for hunting, evidence for hunting practice and remains of animal exploited locally should be checked, as well as the occurrence of wild game in the distribution areas of kites and during the time they were in use, in addition to archaeological evidence proving kites were suitable for a successful hunt.

\subsection{Animal exploitation}

Wild animal remains found at archaeological sites reflect the identity of animals hunted in Armenian sites. However, due to the lack of archaeozoological data, and the lack of studies or preserved bones, we can only extrapolate based on the limited osteological data available.

Twenty one faunal assemblages were found with total NISPu above 100 bones from all archaeological periods - excluding Paleolithic and Mesolithic strata. Wild fauna mostly does not exceed 13\% of NISPu: 13 sites present $0-5 \%, 3$ sites between 5 and $10 \%$ and 2 sites between 10 and 15\%, 2 sites between 23 and 27\% (Tsaghkunk and Garni) and one site has a percentage of wild fauna of $100 \%$ (Tsaghahovit, Chalcolithic: only identified species are included in Fig. 11). Rare remains of wild ungulates (mainly deer, goats and gazelle and to a lesser extent roe deer, wild boar, equids, aurochs and bison) accordingly reflect the scarcity of hunting activities (Fig. 11).

Admitting that no carcass processing was done on site near kite structures means that the processing and the use of hunt products must have been carried out somewhere else. Considering animal bone remains belonging to all chronological periods from across Armenia, the archaeological record lacks processing sites and specialized high consumption sites of wild game, excluding the Paleolithic (Tsaghahovit might be an exception during the Chalcolithic period). No archaeozoological remains have recorded masskilling activities in Armenia. Vereshchagin (1967) is the only scholar to mention mass extinction of wild animals in the Caucasus, but provides no further details. Moreover, mortality profiles, the season of the hunt and the sex of hunted animals are mostly missing due to the scarce bone remains and the lack of detailed analysis of wild fauna from past and recent excavations. Hence the evidence is fragmentary with regards to migration routes, season of hunt and herd or group size, as well as slaughtering practices or transportation of carcasses or body parts.

If we induce that the frequency of animal remains represents the richness of occurrence of this animal in the wild and/or hunting preferences, we could therefore consider that wild goats during the Paleolithic, and wild goats and red deer from the Neolithic onwards, were the predominant species. Nevertheless interpreting the high frequency of wild ungulates in an archaeological assemblage is more complex and is subject to several criteria: a society's game preferences, the availability of prey in a given environment, the season of the hunt, hunting strategies, nutritional benefits in terms of meat and use of raw materials (skins, horn, antler, bones ...), ritual practice, and culinary requirements. Forty-four faunal assemblages have provided data on the presence or absence of wild ungulates in Armenia from the Neolithic onwards with 27 assemblages attesting wild ungulates (Fig. 11, Table 1). Assuming that the list of wild fauna for Armenian prehistoric sites rather reflects the ungulates living in this environment, the preferred prey are red deer and bezoar goat. Boar, gazelle and equids are less noticeable (Figs. 11 and 12). 
Red deer was the major wild game hunted since the Neolithic and is attested at almost all archaeological sites, in all periods (25 sites out of 27). It is a regular and favorite prey if one is to judge from all faunal assemblages (Fig. 12).

Wild bezoar goats (Capra aegagrus) are present in the area of distribution of kites during the Neolithic, Chalcolithic, EBA and MBA (found at 15 sites out of 27; Fig. 11; 12). Paleolithic data suggest an autumn hunt of wild goat in the northeastern mountains of Armenia, particularly at Kalavan-2 and Hovk-1. Female and young individuals were attested at Kalavan-2, in addition to adult individuals at Hovk-1. Bezoar goats have been favorite game throughout the Paleolithic and to a lesser extent until the EBA (Fig. 11).

Gazelle hunting was carried out since the Neolithic in the western part of Armenia. Sites revealing gazelle remains are limited to the known assemblages in the arid steppe and semi-arid areas (Fig. 12). No clear information is available about the season of the hunt, neither are the processing sites or the capture zone known, and the strategy of hunt used remains an open question. Gazelles were found to the northeast of the Aragats region, well to the north of its historical distribution (Fig. 12) and to the north of the zones where kites were constructed (at 12 sites out of 27). Most of the sites near areas with kites yielded gazelle remains (Fig. 12). The hunting of gazelle, according to the frequency of occurrence per site, tends to be more a feature of the Iron Age (Fig. 11).

Other rare wild ungulates are attested in the Armenian spectrum since the Neolithic: roe deer are attested at 9 sites, especially during the Early Bronze Age. Wild boar are clearly identified at 9 sites, particularly during Neolithic and Chalcolithic. Aurochs are so far identified at Neolithic sites in Armavir and from two Chalcolithic sites (Tsaghahovit, Godedzor) in Aragatsotn and Siyunik. Wild horses and onagers are difficult to identify from domestic specimens. Therefore, Equus spp. remains are not included in the general assessment of wild ungulates starting the EBA (Fig. 11). Clear evidence for wild equids are attested from one Neolithic site in Armavir (Aknashen) and four chalcolithic sites in Armavir, Aragatsotn and siyunik (Aknashen, Tekhut, Tsaghahovit and Godedzor). Domestication of horses in the southern Caucasus is under ongoing investigation and has been estimated to occur between the 4th and 2nd millennium BC (Warmuth et al., 2012; Crees and Turvey, 2014). Unidentified equid remains are therefore attested in most assemblages since the EBA (29 sites out of 34 ).

\subsection{Wild ungulates occurrence and habitat range}

Current extant distribution of wild fauna from Armenia, according to IUCN (2009), and zoological data from the region, shows the occurrence in the region of cervid, gazelle, caprines, bovine, equids and boar. These distributions were limited throughout historical times. Combining archaeological and historical data, we are able to chart the occurrence and distribution of wild game in Armenia. Several scholars have recorded biodiversity in the Caucasus (Vereshchagin, 1967; Harrison, 1968; Heptner et al., 1988; Chataigner, 1995; Petrosyan et al., 2001; Meshveliani et al., 2004, 2007). With regards to hunting with kites, the ungulates that are suitable for culling in kites behave in particular ways. These animals are mostly gregarious, live in herds, tend to run in the same direction when threatened, follow regular trails and have a valuable meat or raw material benefit for hunters. The ungulates of this geographic region and those likely to be trapped using a kite are most probably: Ovis sp., Capra sp., Gazelle sp., Cervus sp., Equus sp., Bos sp., and Bison sp. Three species are the main focus of this study, due to their importance in hunting activities in Armenia: red deer (Cervus elaphus), wild goats (Capra aegagrus) and gazelles (Gazella subgutturosa).

\subsubsection{Red deer}

The historical distribution of Red deer (Cervus elaphus) covers the northern slopes of the Greater Caucasus and the western margin of Lake Sevan (Heptner et al., 1988; Williams et al., 2006:12). These herbivores were extinct in Armenia by the 19th century AD (Vereshchagin, 1967:202). Red deer were hunted at almost all archaeological sites recorded in Armenia (Figs. 11 and 12). Cervus elaphus remains are found outside their historical distribution, in the Yerevan and Armavir districts and to the northern region of Aragats Mount (Figs. 11 and 12). Red deer is known for migrating into steppe zones from forested areas during the spring and autumn seasons (Vereshchagin, 1967: 336). In summer, they can be found on the Akhalkalaki plateaus in western Georgia. They are gregarious and live in single sex groups of adult males or females. They can occupy various territorial ranges with a herd size that varies depending on availability of food, shelter, disturbance, and climate. In winter, they aggregate in large herds migrating towards valleys and lowlands. Herds of females of up to 50 individuals, with their fawns, can form in winter (Heptner et al., 1988; Geist, 1998).

\subsubsection{Bezoar goat}

Bezoar or wild goats (Capra aegagrus) live only in areas that are protected today (e.g. the Khosrov Strict Nature Reserve, in southern Armenia). Their historical extent consists of the eastern part of the Greater Caucasus range and of the southern portion of the Lesser Caucasus Mountain chain and southern Highlands (Williams et al., 2006). Bone remains indicate that they have been hunted since the Palaeolithic in the northeastern highlands (Tavush and Gegharkunik), and since the Neolithic in the Aragatsotn, Armavir and Ararat districts (Fig. 12). Wild goats live in rocky and craggy mountains or open-spaces and are resistant to extreme climatic conditions (i.e. cold and snow). Bezoar goats migrate to less snowy areas and lower elevations in winter, where large herds aggregate for breeding. During spring, goats move to higher elevations to search for pastures, and split into solitary males and small young female groups (Zazanashvili, 2009; Gundogdu, 2011). Other goat species, such as the ibex (Capra ibex) for example, tend to run uphill under stress and when pursued are known to jump over low walls (Holzer et al., 2010). Several ethnographic chronicles mention trapping goats within enclosures made of nets on their trails from watercourses, especially during winter, when goats congregate in the gorges of valleys (Jarvis, 1941; Zazanashvili, 2009).

\subsubsection{Goitered gazelle}

Goitered gazelles (Gazella subgutturosa) occur in steppic and semi-desert habitats, as well as in open woodlands. The goitered gazelle is nowadays extinct in Armenia and only survives in natural reserves and parks in Azerbaijan (e.g. in Shirvan National Park, Shirvan Strict nature Reserve and Byandovan Sanctuary; Williams et al., 2006; Mallon and Kingswood, 2001; Mallon, 2008). The historical range of gazelles covers the Araz (Araks valley) in Armenia and the Ighdir lowland on the border between Turkey and Armenia (Vereshchagin, 1967; Turan, 1984; Heptner, 1988; Ölçer, 2001). About 50 to 60,000 gazelles were estimated to be found in the steppe region of southern Caucasia hundreds of years ago (Vereshchagin, 1967:353; Williams et al., 2006:12). Occurrences of goitered gazelle were recorded only from Neolithic strata onward (Fig. 11). According to Vereshchagin (1967: 352), gazelles might have migrated towards Armenia through the northwestern Iranian borderlands around the Neolithic periods. Rare gazelle bone remains have been recorded from Armenian sites especially during the Iron Age periods. Evidence of gazelles being hunted has been identified in the districts of Shirak, Lori, Aragatsotn, Armavir and Siyunik (Fig. 12). Gazelles form large herds during winter season 




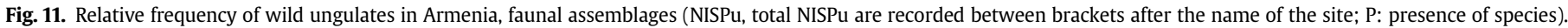



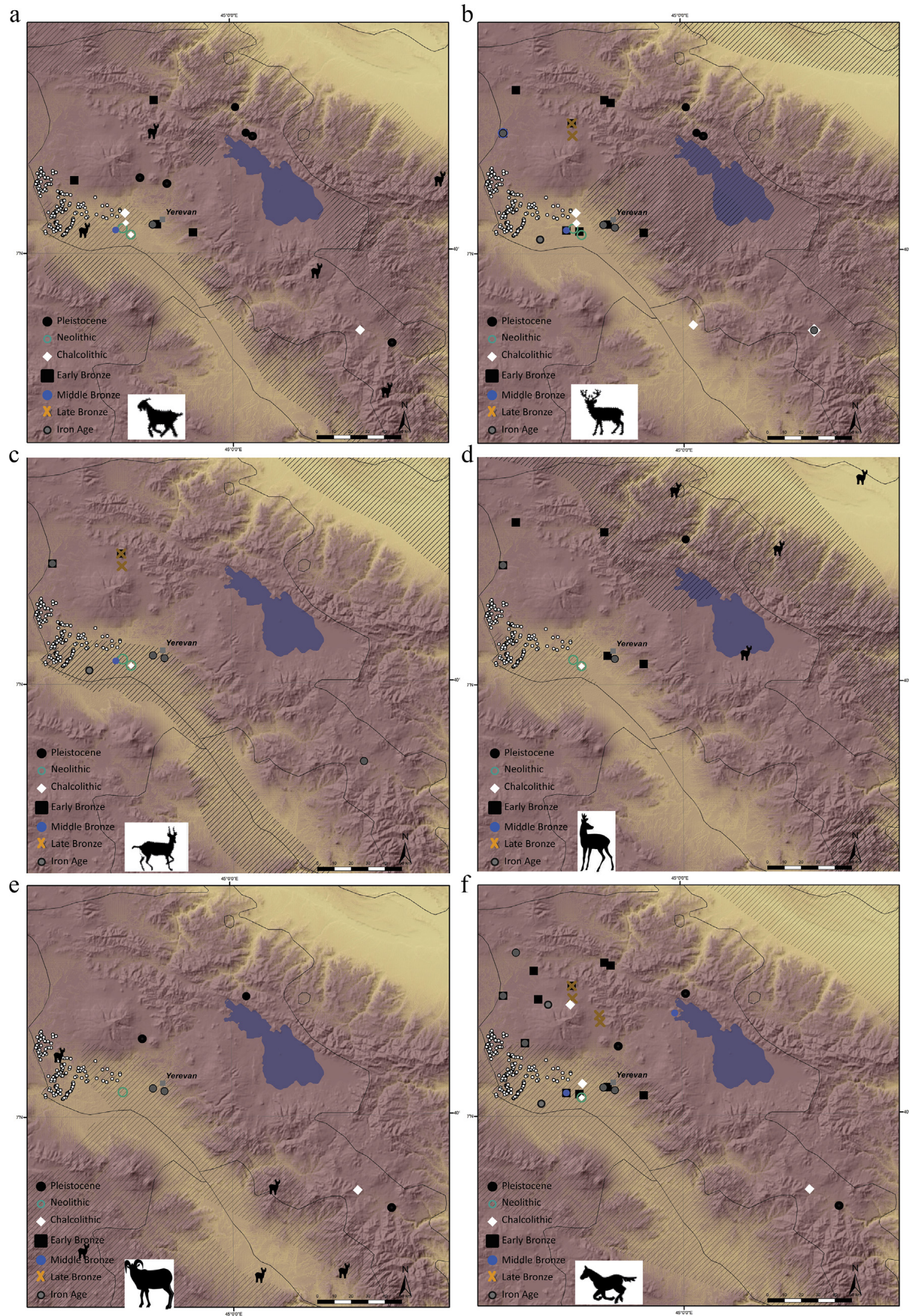

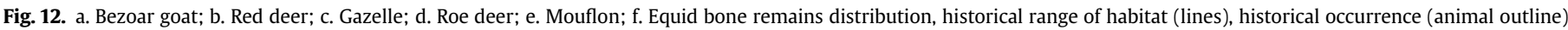
and archaeo-zoological remains/period. Kites are plotted on the map according (white circles). 
and are known to migrate seasonally or following available food and water resources. In summer, they form small groups of females with their offspring and males and can occur at high altitude, for instance in Iran at about $2100 \mathrm{~m}$, and in Afghanistan at about 1000 m (Kingswood and Blank, 1996; Martin, 2000; Mallon and Kingswood, 2001; Ölçer, 2001). They tend to avoid valleys and watercourses as part of their hiding strategy. Gazelles are known to dislike running or jumping without long visibility and they are wary of a predator's presence. During the hot season, they become less active during the day and tend to avoid eastern slopes to avoid the warmth of direct sunlight. Group structures change between the cold and hot seasons. Three configurations are possible: female adults with juveniles, solitary male adults, and sub adult males (Kingswood and Blank, 1996).

\subsubsection{Mouflon}

Ovis orientalis occurs today in southern Armenia, numbering several hundred individuals. Their historical distribution covers the lower parts of the Ghegham and Pambak mountains and the Araks ranges (Fig. 12). Their osteological remains recorded from Holocene archaeological sites are restricted to Armavir district (Fig. 12). Particularly good climbers of sharp mountain slopes, mouflons inhabit the high summits in summer and lowlands and valleys in winter (Vereshchagin, 1967; Heptner, 1988; Zazanashvili, 2009). Large herds were seen migrating from the Araks valley to northern Iran to avoid the winter cold (Zazanashvili et al., 2009). However, due to the occurrence of herds in Turkey (Williams et al., 2006), other migration routes are plausible between Mount Ararat, the Allahuekber Mountains in Eastern Turkey, the Turkish-Iranian border and Armenia's western districts.

\subsubsection{Horse and onager}

Historical encounters mention the occurrence of wild horses and onagers in the Araks steppe and plain, north of Ararat until the 11-12th centuries $A D$, and describe the royal hunt of equids around the 4th century AD, as well as communal hunts carried out in Armenia by encircling equids in enclosures (Heptner et al., 1988:715). The home range of these two species of equids is not precisely known (Vereshchagin, 1967; Heptner, 1988; Bendukidze, 2010). In addition, their preferences in terms of habitat and favorite food, their water needs and the size of their territory differ slightly, but they share common behavior patterns. Equid bones, wild and/or domestic remains, are attested in Holocene Armenian sites around areas with kites in the districts of Armavir, Aragatsotn, Shirak and Lori. Neolithic and Bronze Age remains only are shown in Fig. 12 for the district of Armavir. Horse remains are noted for Iron Age burials in the Sevan Basin, according to Vereshchagin (1967: 324), as well as probable wild ass or onagers from prehistoric sites in the Armavir district, according to Crees and Turvey (2014). Horses and onagers form complex social structures, with polygamous and bachelor groups, aggregating in herds around watercourses and migrating seasonally to form large herds in autumn. Their population size can differ even seasonally, generally depending on the amount of available food - from less than ten to several hundred animals - (Klingel, 1977; Krueger, 2008).

\subsubsection{Roe deer}

Roe deer distribution covers the steppic zone to the southern shores of Lake Sevan (Vereshchagin, 1967; Heptner et al., 1988). Hunting activities of roe deer are recorded at all archaeological sites, such as in animal bone remains in the districts of Shirak, Yerevan, Armavir, Lori and Ararat (Figs. 11 and 12). Roe deer is not a gregarious species, but tends to form small herds (about ten animals) in winter.

\subsubsection{Aurochs and bison}

Aurochs (Bos primigenius) inhabited open landscapes to the South and in the Armenian highlands. They became extinct by the 17 th century AD. They used to live in small herds, especially in winter (Vereshchagin, 1967; Heptner et al., 1988). The Caucasian bison (Bison bonasus caucasicus) became extinct by the 19th century AD (Vereshchagin, 1967:202; Heptner et al., 1988). It inhabited the forested steppe and the mountain forest zone. Aurochs and Bison remains were identified at Middle Paleolithic and Mesolithic sites, as well as at Neolithic sites of the Armavir region (Aknashen and Aratashen), and at Chalcolithic settlement of Armavir and Siyunik (Tsaghahovit, Godedzor) (Fig. 11).

\subsection{Kite distribution and migration routes}

The distribution of kites in Armenia partly coincides with the habitat range of gazelle, bezoar goat, red deer, horse, onager and mouflon. These animals are known to migrate in herds. Herd size correlates to the season, and herds mostly comprise female and young individuals and small groups of lone males. Zoological data reveals that the migration routes of mouflons occur in an area from the Araks valley to northern Iran (Vereshchagin, 1967; Heptner et al., 1988). To the best of our knowledge, no clear evidence is known regarding migration routes for other particular ungulates, particularly gazelles and bezoar goats. Seasonal movements from upper to lower elevations between winter and summer are general behavior criteria for bezoar goats and red deer and probably also for gazelle, influenced by the specific ecological characteristics of the southern Caucasus (Harrison, 1968; Martin, 2000; Mallon and Kingswood, 2001; Durmus, 2010).

In contrast, according to the Ecosystem Caucasian Development Program (Williams et al., 2006), several wildlife corridors and migration routes are plausible around the distribution areas of kites. Several wildlife corridors are located between Kars, Arpachay and Ighdir in eastern Turkey, Shirak, Aragatsotn, Armavir in Armenia and northwest Iran (Fig. 13).

\subsection{Rock art and ethnographical data}

Rock art, mostly engravings, are widespread over the territory of Armenia. Engravings depicting hunting scenes are manifold and illustrate animals and hunters. Wild goat, cervids, aurochs, bison and carnivores are the recurrent hunted game depicted in Armenian rock art. The most well-known desert kites engraved with hunting scenes are found notably in Syria, Jordan, and Arabia (Harding, 1953; Betts and Helms, 1986; Hershkovitz et al., 1987; MacDonald, 2005; Picalause et al., 2004; e.g.; Crassard et al., 2014). Rare kite-like structures are suggested by depictions on a few engravings in Armenia, dated roughly around the 3rd and the 2nd millennium BC. Carvings of animals, mainly goats, are shown being driven and trapped inside enclosures. They are found from the Gegham Mountains in Kotayk district to the Siyunik district (Karakhanyan and Safyan, 1970; Martirosyan and Israelyan, 1971, Fig. 14a). One particular case from Siyunik district is noteworthy, and depicts a rectangular structure with a feline inside of an enclosure with a probable goat figure on the outside (Karakhanyan and Safyan, 1970; Martirosyan and Israelyan, 1971; Manaseryan, 2003). This structure bears a striking resemblance to a kite, with its enclosure, antennae, entrance and a cell (or a pit) at the end. The feline inside is interpreted by Manaseryan (2003:198) as a hunting companion used to help chasing preys inside the enclosure (Fig. 14c). This hypothesis is plausible as historical data describe Armenian princes around the 15th century AD using felids probably cheetah (Acinonyx jubatus) as hunting companions (Vereshchagin, 1967: 282). A particular interpretation of another 
engraving from the Gegham mountains was given by Manaseryan (2003:198) who mentions a hunting scene, labeled a "battue hunt", where hunters/beaters, depicted with their hands-up, are trapping and encircling a wild goat (Fig. 14b). Historical records mention hunting activities of Armenian kings during the 1st and 2nd centuries AD in the middle Araks valley. These rulers focused on wild boars and onagers (Vereshchagin, 1967:128). Georgian and Iranian chronicles report elite communal hunting of large quantities of deer during the Middle Ages: 'prince hunted 180 deer in one day, Czar 60 deer and other animals' (Vereshchagin, 1967:339). Such communal hunts provide the possibility of culling large quantities of wild fauna in Armenia. These practices could be mirrored by the use of hunting techniques involving kite-like structures.

Ethnographic descriptions reveal that Caucasian hunters often carried on mountain trails $30-40 \mathrm{~kg}$ of wild goat, gazelle, or swine meat over distances of 20-25 km (Vereshchagin, 1967:11). Shrines of horns and skull of wild goats and deer were found in Dagestan and Northern Transcaucasia (Vereshchagin, 1967:202). These data suggest a probable practice to transport carcass from capture zones of wild fauna (like kites) to settlement areas. Such an amount of meat also suggests a substantial number of killed animals.

\section{Discussion: validating the hunting hypothesis}

Two types of kite structures were recorded in Aragats Mount, according to Brochier et al. (2014): kites with antennae and those without. The kites with antennae are characterized by an enclosure following slope breaks, by uphill running antennae, pointed appendixes or proximal cells, and an entrance with an edge or threshold. A distinction was observed between large enclosures with long antennae at lower altitudes and small enclosures with short antennae at higher altitudes. Other structures similar to kites with the presence of large enclosures and cells diverge because of the absence of slope breaks and of antennae. These were recorded in the highlands ( $>1000 \mathrm{~m}$ altitude).

Most entrances to kites are open towards the northeast, and several enclosures present partitions made of constructed walls or opportunistically using the available rocky protuberances (Fig. 15b). Evidence of the past existence of herbivores in the surroundings of kites was suggested by the analyses of microalgae and anthropogenic dust in the sediments (Brochier et al., 2014). The difference in the size of enclosures and the length of antennae are to be considered whether they are correlated with the prey targeted. The presence of the hidden enclosure in a slope break is generally interpreted as evidence of the use of these structures for hunting.

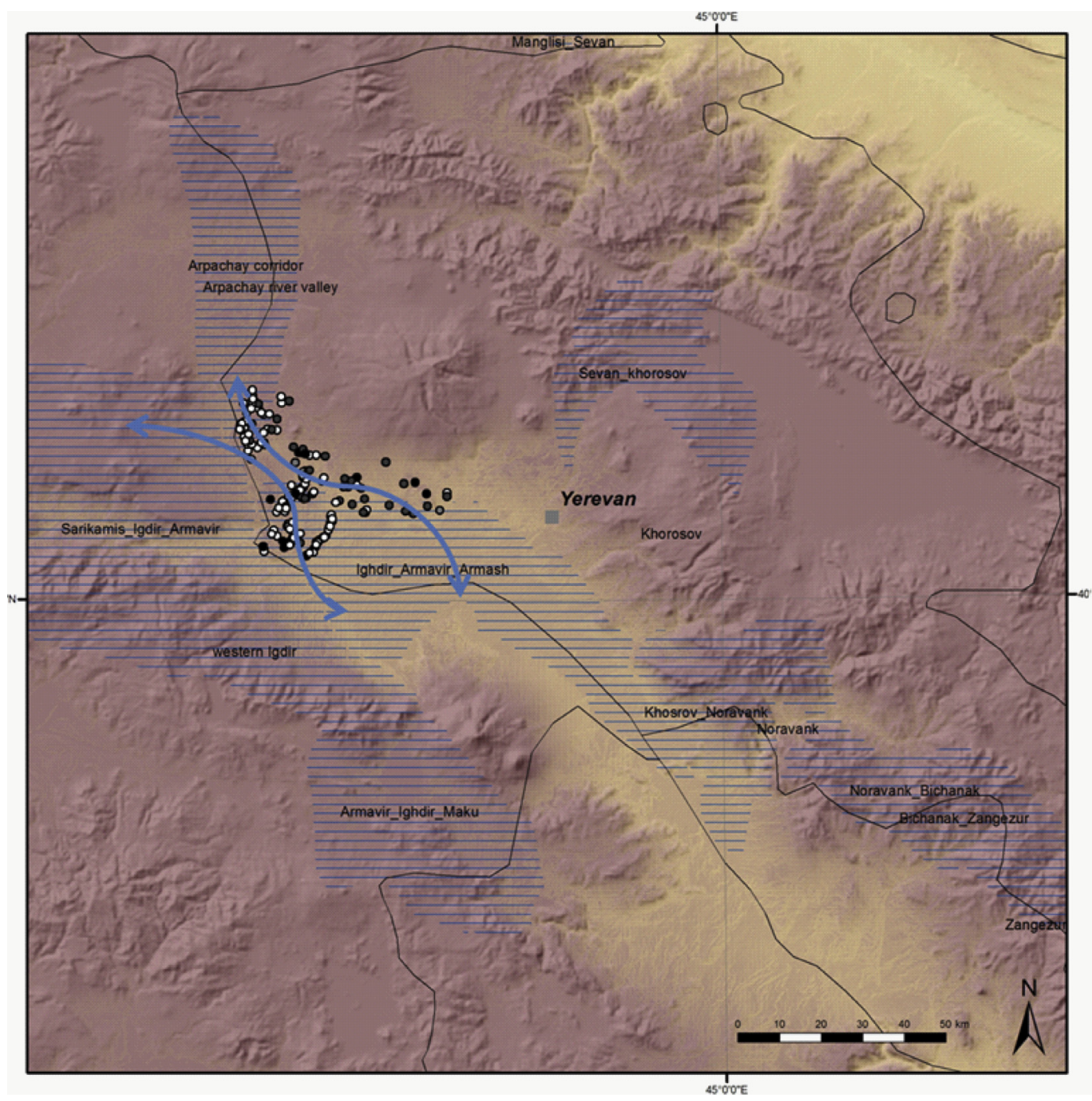

Fig. 13. Wildlife corridor (lines) and plausible migration circulation (arrow), based on data from Williams et al., 2006. 


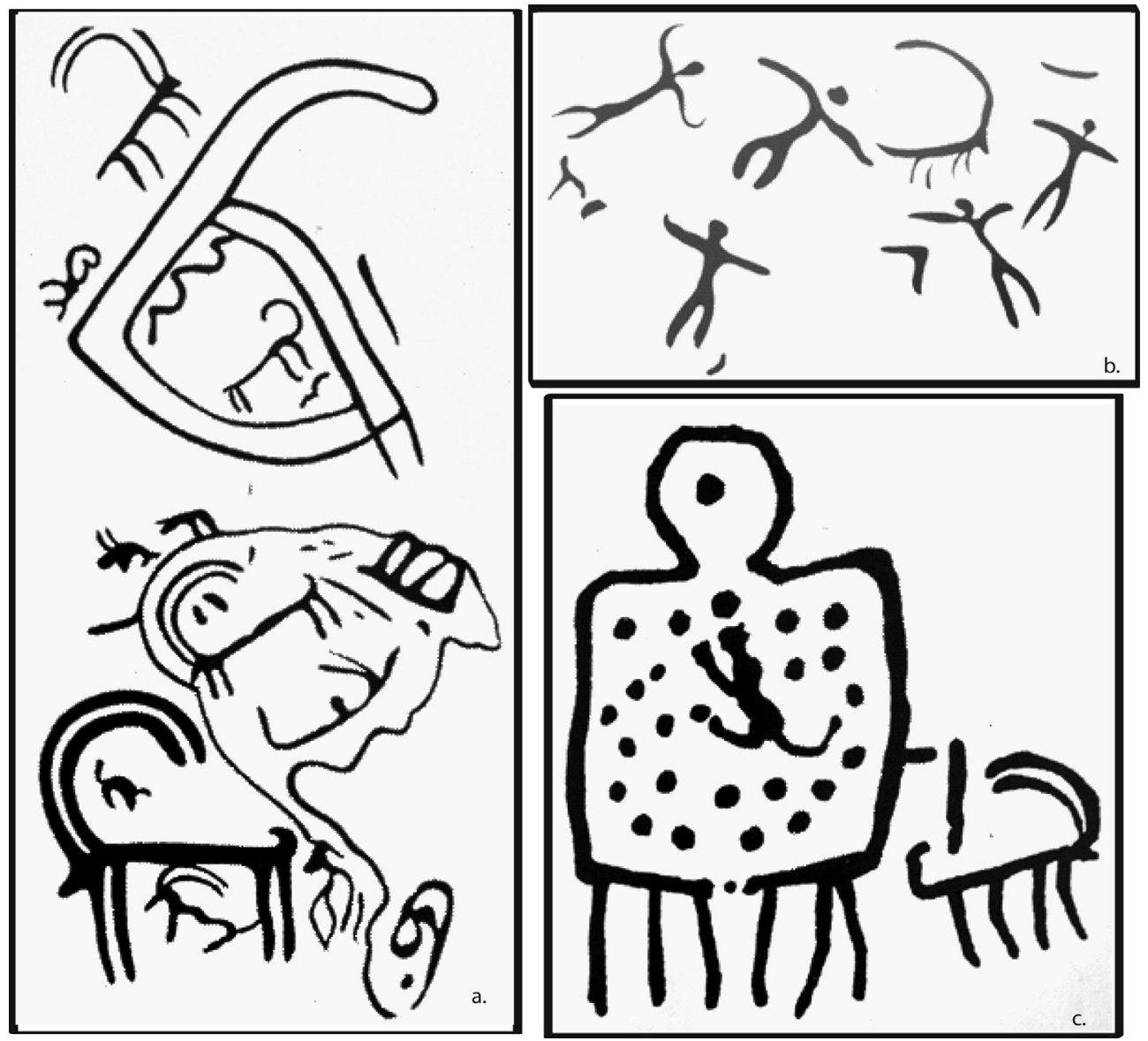

Fig. 14. Engravings of wild animals inside enclosures, circled by hunters (Karakhanyan and Safyan, 1970; Martirosyan and Israelyan, 1971).

The chronology of kite construction and use is still under study. Nevertheless, recent analyses of sediments, dust and lichens, along with radiocarbon dating, enable an estimation of the date of construction and use somewhere between the EBA and Late Iron Age (Brochier et al., 2014). Scholars have long argued in favor of the hunting hypothesis while studying kites and have dismissed relating these structures to animal husbandry (Rosen and Perevolotsky, 1998; Fowden, 1999; Holzer et al., 2010; Bar-Oz et al., 2011; Bar-Oz and Nadel, 2013; Zeder et al., 2013).

In the Armenian kites, compiling zoological and zooarchaeological studies with archaeological investigation (excavations, GIS studies, geo-archaeology) allows us to ascertain that kite structures had a hunting function. Nevertheless, when analyzing the presence of similar structures without antennae recorded in Armenia (Brochier et al., 2014), both hunting and animal husbandry functions should be investigated. These structures include large enclosed surfaces that, according to Brochier et al. (2014:34), are larger than 'classical pastoral enclosures'. However, when taking into account the absence of features such as antennae and slope breaks, and correlating enclosures to their distribution in the highlands, one should not disregard a possible alpine pastoral use of kites in that particular area. Transhumance activities are widespread in the highlands of Armenia and the region of Shirak is considered alpine pastoral land during summer (Mkrtumyan, 1974). In addition, in Armenia, according to animal bone remains, sheep and goats husbandry was the main subsistence strategy since the Neolithic period. At present, archaeozoological data regarding ancient livestock mobility and transhumance practices are not yet clearly available from the southern Caucasus.
With regards to the kites identified by Brochier et al. (2014:34), recent analyses have revealed that these kites with antennae tend to have smaller enclosures and shorter antennae at higher altitudes. Ethological studies reveal that large herds of ungulates congregate in winter before the mating season; during winter, therefore, most wild ungulates inhabit low altitude areas, deep valleys and canyons in order to avoid snow, to look for a shelter from winds and to search for food resources (Basken and Danell, 2010). The location of kites at low and high altitudes, in valleys and along slope breaks, could reflect an accurate knowledge of animal ethology and behavior, and be useful in hunting gazelles, goats and deer during the winter season, since thousands of animals are found together across the lowlands. High altitude kites are smaller in size, a characteristic that suits the capture of small herds moving to highlands during summer. These herds are made up of female young animals or lone males, forming in the case of gazelle some 10 to 30 individuals per group (Kingswood and Blank, 1996). The correlation between altitude and kite size could then be linked to the season of the hunt and to herd size.

Kites at higher altitudes $(1000-1600 \mathrm{~m})$ could be for targeting small group of ungulates during the summer season, while those at lower altitude $(800-1000 \mathrm{~m})$ may be meant to trap large herds during the winter season. Whereas wild goats have a higher habitat range during winter, they can be found in large herds between 1500 and $2000 \mathrm{~m}$ during the mating season. Hence the purpose of the northern concentration of kites might have been for specialized wild goat hunt, while the southern kites might have been efficiently used for the culling of gazelles. Nevertheless, gazelles can also inhabit high altitudes up to $3000 \mathrm{~m}$ during warmer summers. 




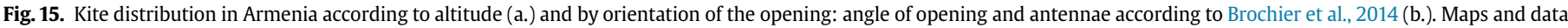
relating to kites data are generated from a GIS database, Globalkites ANR project.

Most scholars consider that kites were a trap for hunting large herds. Consequently, hunted ungulates should be mirrored in human diet and economy. According to our overview of hunting activities and animal remains recorded in Armenia, mass hunts or very intensive exploitation of wild ungulates is not evident at any archaeological period. Current analyses of kites suggest they were used between the 3rd and the 1st millennium BC (Brochier et al., 2014). Hunting activities during these periods do not reduce the potential span of time kites were used, nor link their use to a single phase. Furthermore, a principal species of prey cannot be identified. According to faunal remains at archaeological sites, red deer are the regular hunted games across the Holocene, while wild goats were mostly hunted during the Chalcolithic and gazelles during the Iron Age.

The kite antennae of low height were meant to drive the animals toward enclosures. Wild ungulates have slightly different behaviors as regards obstacles and fences. Antelopes in general tend to run alongside low walls until they find an opening to avoid jumping over the fence. Gazelle, furthermore, memorize fences by adopting the same behavior even when only parts of the walls are present (Lubinski, 1999; Mallon and Kingswood, 2001). In contrast cervids, bovines and caprines require long, larger and/or solid fences to prevent them from jumping over and to drive them between walls (Lubinski, 1999). The low height of antennae recorded in Armenia is considered to have been intentional, and no evidence has yet been found of higher walls or of an organic expanded superstructure.

The funnel entrance recorded in 55\% of Armenian kites (Brochier et al., 2014) could be meant to confuse animals once they were driven inside the enclosure, and to prevent them from finding the exit. The orientation of kites would have directed movements through the entrance. Most kites show an orientation of the opening towards the west and northeast and are mainly induced by slope directions (Brochier et al., 2014, Fig. 15). Available data on animal migrations and plausible migration corridors reveal a probable correlation with kite orientation (Fig. 13; 15). If we consider that animals migrate through corridors (Fig. 13) from northern Armenia and eastern Turkey toward southern Armenia, Nakhichivan and northern Iran, the sequence (or group) of kites form clear and deliberate obstacles, as well as an efficient driving trap for wild game. Hence, two patterns of mobility can be deduced from northeastern to south-western Armenia and from southeastern to north-western Armenia (Fig. 13). The seasonal migration from low to high altitudes might also correlate with the orientation of kites and relate directly to the orientation of slopes.

Most small bovids tend to run and hide in cliffs under the pressure of predators (Caro et al., 2004). Enclosures hidden by topography, mostly those behind slopes, were probably intended to conceal the traps, whereas animals were to be driven toward them after following the straight lines of antennae. This feature was certainly useful with ungulates like gazelles, goats and equids, animals that are sight-vigilant. Gazelles are also known to have poor wide vision range (Kingswood and Blank, 1996). In addition, gazelle and red deer avoid climbing or descending slopes but, when pressured, can run downhill at full speed (Mendelssohn, 1974), while wild goats can run uphill when frightened (Gundogdu, 2011). Wild goats were considered less favorable for hunting with kites due to this. Meanwhile, wild goats were not considered as targeted prey by kites due to the fact that antennae in a particular zone as the Negev and Sinai were constructed downhill, according to Holzer et al. (2010:815). However, in Armenia kites antennae were built uphill. Goats, therefore, could have been a possible prey.

Most of the cells are in a proximal position near the entrance of the kites, and have lower floor-levels than enclosures (Brochier et al., 2014). Does this relate to hiding pits of driveline traps, used by hunters hiding and waiting to kill or trap the animals? The difference in floor-levels between the enclosure and the cells could be related to animal control inside the enclosure, to the channeling of prey toward cells, and be meant to force them to leap over and fall inside the pitfalls in the cells. Ethnographic chronicles have mentioned these hunting techniques in America (for goats and cervids) and the Middle East (for gazelle) (Burckhardt, 1831; Jarvis, 1941; Steward, 1943; Vereshchagin, 1967:374; Custred, 1979). Nevertheless, gaps in enclosure walls that allow directing the animals toward cells are mostly missing from Armenian kites (Brochier et al., 2014). Holzer et al.(2010:814) considered cells or pits built on slope breaks in the case of the Negev and Sinai kites as 
compatible with equid (asses/onagers) trapping. Further investigation regarding the architecture of cells is being carried out by the Globalkites project in Armenia and other regions of the Middle East and Central Asia (Crassard et al., 2014; Barge et al., 2015a,b. The double-stoned course of walls in the cells (Brochier et al., 2014) should be considered as an obstacle to prevent ungulates from leaping and jumping outside if they are trapped inside. Goats, gazelles and cervids tend to jump over obstacles while running under pressure from predators (Kingswood and Blank, 1996; Geist, 1998; Gundogdu, 2011). When not frightened, gazelles and onagers tend to follow low wall fences and not cross over them. Wild goats are efficient climbers and need thick walls to keep them trapped, while bison need solid walls and deer require long fences to prevent them from jumping over (Klingel, 1977; Lubinski, 1999). Most of the cells have walls two meters high with the tops leaning inwards (Brochier et al., 2014). This latter feature could prevent ungulates, particularly cervids and probably equids, from jumping outside the cell (Lubinski, 1999). According to ethnographic records from North America, cervids were trapped inside corrals or pits with 'posts leaning inward, so that the deer could leap in but not out' (Steward, 1943:359). Using the landscape for building enclosures and cells as well as partitions (Brochier et al., 2014) could be features meant to intentionally camouflage the trap, so the animal would not notice the difference between the enclosure's interior and exterior (Mendelssohn, 1974: 726-727).

\section{Conclusion}

The available data on kites and fauna in Armenia tends to confirm the hypothesis of a hunting function for kite structures, with probably different wild games targeted: gazelles, wild goats and red deer. All these three species were native to the distribution area of kites in Armenia. Nevertheless, further studies and other methods of investigation are needed to confirm this assertion. To what extent were animals recorded from archaeological sites hunted with Armenian kites? Determining the wild game catchment zone could lead to a better understanding of the function of kites, and to finding the missing link between settlement sites and the kites themselves.

A question remains: how were these kite structures actually used by humans? Further excavation of kite structures and study of animal remains from archaeological sites are needed to explore this and to correlate kites with cultural and chronological data.

\section{Acknowledgements}

This research was conducted under the Globalkites ANR project, funded by the Agence Nationale de la Recherche, France (2013-2017, No. ANR-12-JSH3-0004-01, to R. Crassard). Zooarchaeological studies at Aknashen, Aratashen, Godedzor, Kmlo and Tsghahovit were funded by the 'Ministère des Affaires étrangères, France'. We acknowledge the discussion and the help provided by Christine Chataigner (CNRS, UMR 5133 Archéorient, France). We wish to thank the editors of the proceedings of the LIA conference in Lyon for their invitation to contribute to this volume. We wish to acknowledge the help of Oliver Barge and Emmanuelle Régagnon (CNRS, UMR 5133 Archéorient, Jalès) with using of ArcGIS kites database. Thanks to Jacques-Elie Brochier for useful discussion and comments.

\section{References}

Adler, D.S., Bar-Oz, G., Belfer-Cohen, A., Bar-Yosef, O., 2006. Ahead of the game middle and upper Palaeolithic hunting behaviors in the southern Caucasus. Current Anthropology 47, 89-118.
Adler, D.S., Yeritsyan, B., Wilkinson, K., Pinhasi, R., Bar-Oz, G., Nahapetyan, S., Mallol, C., Berna, F., Bailey, R., Schmidt, B.A., Glauberman, P., Wales, N., Gasparyan, B., 2012. The hrazdan gorge palaeolithic project, 2008-2009. In: Avetisyan, P., Bobokhyan, A. (Eds.), Archaeology of Armenia in Regional Context, Proceedings of the International Conference Dedicated to the 50th Anniversary of the Institute of Archaeology and Ethnography Held on September 15-17, 2009 in Yerevan. National Academy of Sciences of the Republic of Armenia "Gitutyun" Publishing House, Yerevan, pp. 21-37.

Adler, D.S., Tushabramishvili, N., 2004. Middle Paleolithic patterns of settlement and subsistence in the southern Caucasus. In: Conard, N.J. (Ed.), Settlement Dynamics of the Middle Paleolithic and Middle Stone Age, vol. II. Kerns Verlag, Tübingen, pp. 91-133.

Badalyan, R., Avetisyan, P., 2007. Bronze and Early Iron Age Archaeological Sites in Armenia I: Mt Aragats and its Surrounding Region. British Archaeological Reports International Series. Oxford.

Badalyan, R., Harutyunyan, A.A., Chataigner, C., Le Mort, F., Chabot, J., Brochier, J.E., Bălășescu, A., Radu, V., Hovsepyan, R., 2010. The settlement of AknashenKhatunarkh, a neolithic site in the ararat Plain (Armenia): excavation results 2004-2009. TÜBA-AR 1, 185-218.

Badalyan, R., Lombard, P., Avetisyan, P., Chataigner, C., Chabot, J., Vila, E., Hovsepyan, R., Willcox, G., Pessin, H., 2007. New data on the late prehistory of the southern Caucasus. The Excavations at Aratashen (Armenia): preliminary report. Les cultures du Caucase (VI-III ${ }^{\text {me }}$ millénaires av. n. è.). Leurs relations avec le Proche-Orient. In: Lyonnet, B. (Ed.), Actes de la Table Ronde de Saint Pétersbourg, Février 2004. Paris, pp. 37-62.

Badalyan, R.S., Kohl, P.L., Stronach, D., Tonikian, A.V., 1994. Preliminary report on the 1993 excavations at horom, Armenia. Iran XXXII, 1-29.

Bălăşescu, A., 2008. La faune de Tsaghahovit. In: Arimura, M., Chataigner, C. (Eds.), Rapport de la mission française en Arménie pour le Ministère des Affaires étrangères, France, pp. 57-58.

Bălășescu, A., 2009. La faune de L'établissement Chalcolithique de Godedzor. In: Avetisyan, P., Kalantaryan, I., Palumbi, G., Chataigner, C., Balasescu, A., Hovsepyan, R. (Eds.), Rapport de la mission française en Arménie pour le Ministère des Affaires étrangères, France, pp. 88-90.

Bălăşescu, A., 2010. La faune des mammifères de Kmlo-2. In: Chataigner, C. (Ed.), Rapport de la mission française en Arménie pour le Ministère des Affaires étrangères, France.

Bălășescu, A., Vila, E., Radu, V., Badalyan, R., Chataigner, C., 2010. Production animale et économie de subsistence au Néolithique dans la plaine de l'Ararat (Arménie). Annales d'Université "Valahia" Târgoviște - Section d'Archéologie et d'Histoire 12 (1) 25-38.

Barge, O., Brochier, J.É., Chambrade, M.-L., Régagnon, E., Crassard, R., 2015a. From local to global scale: a comparative study of kites between the core area in Jordan and its distant periphery. Arabian Archaeology and Epigraphy 26.

Barge, O., Brochier, J.É., Crassard, R., 2015b. Morphological diversity and regionalization of kites in the Middle East and Central Asia. Arabian Archaeology and Epigraphy 26.

Barge, O., Brochier, J.É., Chahoud, J., Chataigner, C., Chambrade, M.-L., Karakhanyan, A., Régagnon, E., Crassard, R., 2013. Towards a new approach to the 'kites phenomenon' in the Old World: the GLOBALKITES Project. Antiquity 87 (338). Project Gallery. Available at: http://antiquity.ac.uk/projgall/barge338/ (accessed 07.01.15.).

Bar-Oz, G., Belfer-Cohen, A., Meshveliani, T., Djakeli, N., Bar-Yosef, O., 2008. Taphonomy and zooarchaeology of the Upper Palaeolithic cave of Dzudzuana, Republic of Georgia. International Journal of Osteoarchaeology 18, 131-151.

Bar-Oz, G., Nadel, D., 2013. Worldwide large-scale trapping and hunting of ungulates in past societies. Quaternary International 297, 1-7.

Bar-Oz, G., Zeder, M., Hole, F., 2011. Role of mass-kill hunting strategies in the extirpation of Persian gazelle (Gazella subgutturosa) in the northern Levant. PNAS 108 (18), 7345-7350.

Bar-Oz, G., Weissbrod, L., Gasparian, B., Nahapetyan, S., Wilkinson, K., Pinhasi, R., 2012. Taphonomy and zooarchaeology of a high-altitude Upper Pleistocene faunal sequence from Hovq-1 Cave, Armenia. Journal of Archaeological Science 39, 2452-2463.

Bar-Yosef, O., Belfer-Cohen, A., Mesheviliani, T., Jakeli, N., Bar-Oz, G., Boaretto, E., Goldberg, P., Kvavadze, E., Matskevich, Z., 2011. Dzudzuana: an Upper Palaeolithic cavesite in the Caucasus foothills (Georgia). Antiquity 85, 331-349.

Basken, L., Danell, K., 2010. Ecology of Ungulates: a Handbook of Species in Eastern Europe and Northern and Central Asia. Springer Berlin, Heidelberg.

Bendukidze, O., 2010. The Jinisi horse: and some thoughts on the role of the onager in the Bronze Age). In: Erkomaishvili, N., Kvirkvelia, G., Narimanishvili, G., Sadradze, V., Tsereteli, M., Tskvitinidze, Z. (Eds.), Rescue archaeology in Georgia: Baku,-tbilisi- Ceyhan and South Caucasian Pipelines. Georgian National Museum, Tbilisi, pp. 266-274.

Berthon, R., 2014. Past, current, and future contribution of zooarchaeology to the knowledge of the neolithic and chalcolithic cultures in south caucasus. Caucasian Archaeology 2, 4-30.

Berthon, R., Decaix, A., Kovács, Z.E., Van Neer, W., Tengberg, M., Willcox, G., Cucchi, T., 2013. A Bioarchaeological investigation of three chalcolithic pits at ovçular tepesi (Nakhchivan, Azerbaijan). Environmental Archaeology 18 (3), 191-200.

Betts, A.V.G., Helms, S., 1986. Rock art in eastern Jordan: kite carvings? Paléorient 12 (1), 67-72.

Brochier, J.É., Barge, O., Karakhanyan, A., Kalantaryan, I., Chataigner, C., Chambrade, M.-L., Magnin, F., 2014. Kites on the margins. The Aragats kites in Armenia. Paléorient 40 (1), 25-53. 
Burckhardt, J.L., 1831. Notes on the Bedouins and Wahabys, collected during his travels in the east. In: Association for Promoting the Discovery of the Interior of Africa (Vol. 2). Colburn and Bently, London.

Caro, T.M., Graham, C.M., Stoner, C.J., Vargas, J.K., 2004. Adaptive significance of antipredator behaviour in artiodactyls. Animal Behaviour 67 (2), 205-228.

Chahoud, J., 2013. La faune de Godedzor. In: Chataigner, C. (Ed.), Rapport de la mission française en Arménie pour le Ministère des Affaires étrangères, France, pp. 30-37.

Chahoud, J., Vila, E., Crassard, R., 2015. Archaeozoological approach in understanding the 'desert kites'. Arabian Archaeology and Epigraphy 26.

Chataigner, C., 1995. La Transcaucasie au Néolithique et au Chalcolithique. Oxford.

Chataigner, C., Gasparyan, B., Montoya, C., Arimura, M., Melikyan, V., Liagre, J., Petrosyan, A., Ghukasyan, R., Colonge, D., Fourloubey, C., Arakelyan, D., Astruc, L., Nahapetyan, S., Hovsepyan, R., Bălăsescu, A., Tomé, C., Radu, V., 2012. From the Late Upper Paleolithic to the Neolithic in north-western Armenia: preliminary results. In: Avetisyan, P. (Ed.), Proceedings of the International Conference "The Archaeology of Armenia in a Regional, Context: Results and Perspectives", Yerevan, 14-19 September 2009, pp. 37-43\& 157-162.

Crassard, R., Barge, O., Bichot, Ch-E., Brochier, J.E., Chahoud, J., Chambrade, M.-L. Chataigner, C., Madi, K., Régagnon, E., Seba, H., Vila, E., 2014. Addressing the desert kites phenomenon and its global range through a multi-proxy approach. Journal of Archaeological Method and Theory 21 (3). http://dx.doi.org/10.1007/ s10816-014-9218-7.

Custred, G., 1979. Hunting technologies in Andean culture. Journal de la Société des Américanistes 66, 7-19.

Crees, J.J., Turvey, S.T., 2014. Holocene extinction dynamics of Equus hydruntinus, a late-surviving European megafaunal mammal. Quaternary Science Reviews 91, $16-29$.

Durmuş, D., 2010. Determination of Home Range Size and Habitat Selection of Gazelles (Gazella Subgutturosa) by Gps Telemetry in Sanliurfa (Masters thesis). Middle East Technical University, Turkey.

Échallier, J.-C., Braemer, F., 1995. Nature et fonction des « Desert Kites »: données et hypothèses nouvelles. Paléorient 21 (1), 35-63.

Frangipane, M., Palumbi, G., 2007. Red-black Ware, pastoralism, Trade, and Anatolian-Transcaucasian Interactions in the 4th-3rd millennium B.C. In: Lyonnet, B. (Ed.), Les Cultures du Caucase (VIe-IIIe Millénaires avant notre ère): Leurs Relations avec le Proche-Orient. CNRS éditions, Paris, pp. 233-255.

Fowden, G., 1999. 'Desert kites': ethnography, archaeology and art. In: Humphrey, J.H. (Ed.), The Roman and Byzantine Near East: Some Recent Archaeological Research. Journal of Roman Archaeology: Supplementary Series 31 vol. 2, 107-136.

Gasparyan, B., Khechoyan, A., Bar-Oz, G., Malkinson, D., Nachmias, A., Nadel, D., 2013. The northernmost kites in south-west Asia: the fringes of the Ararat Depression (Armenia) Project. Antiquity 87 (336). Project Gallery. http:// antiquity.ac.uk/projgall/bar-oz336/ (accessed 14.04.14.)

Geist, V., 1998. Deer of the World: Their Evolution, Behaviour, and Ecology. Stackpole Books, Pennsylvania.

Ghukasyan, R., Colonge, D., Nahapetyan, S., Ollivier, V., Gasparyan, B., Monchot, H. Chatainger, C., 2011. Kalavan-2 (North of Lake sevan, Armenia): a new late middle palaeolithic site in the lesser caucasus. Archaeology, Ethnology \& Anthropology of Eurasia 38, 39-51.

Grayson, D.K., 1979. On the quantification of vertebrate archaeofaunas. In: Schiffer, M.B. (Ed.), Advances in Archaeological Method and Theory (Vol. 2) Academic Press, New York, pp. 199-237.

Gundogdu, E., 2011. Population size, structure and behaviours of wild goat in Cehennemdere wildlife improvement area. Asian Journal of Animal and Veterinary Advances 6, 555-563.

Harding, G.L., 1953. The cairn of Hani. Annual of the Department of Antiquities of Jordan 2, 8-56.

Harrison, D.L., 1968. The Mammals of Arabia (Vol IIth ed.). Ernest Benn Ltd, London.

Hershkovitz, I., Ben-David, Y., Arensburg, B., Goren, A., Pinchasov, A., 1987. Rock engravings in southern Sinai. In: Gvirtzman, G., Shmueli, A., Gardos, Y., BeitArieh, I., Harel, M. (Eds.), Sinai Part 2, Human Geography/Gvirtzman Gdaliahu. Eretz Ha-Tzvi, Givatayim, pp. 605-616.

Heptner, V.G., Nasimovich, A.A., Bannikov, A.G., Hoffman, R.S., 1988. Mammals of the Soviet Union, Vol. I. Smithsonian Institution Libraries and National Science Foundation, Washington, D.C.

Holzer, A., Avner, U., Porat, N., Horwitz, L.K., 2010. Desert kites in the Negev desert and northeast Sinai: their function, chronology and ecology. Journal of Arid Environments 74 (7), 806-817.

IUCN, 2009. IUCN Red List of Threatened Species. http//www.iucnredlist.org. Downloaded on 18 November 2015.

Jarvis, C.S., 1941. Yesterday and today in sinai. In: Blackwood, W. (Ed.) (Edinburgh).

Kandel, A.W., Gasparyan, B., Nahepetyan, S., Taller, A., Weissbrod, L., 2014. The upper paleolithic settlement of the armenian Highlands. In: Otte, M. (Ed.) Modes of Contacts and Displacements during the Eurasian Paleolithic, Conference Proceedings, Liège, 29-31 May 2012. ERAUL 140. Luxembourg, pp. 39-60.

Karakhanyan, G.O., Safyan, P.G., 1970. Rock Carving in Siunik. Issue 1. Publishing house of Academy Sciences of Armenia, Yerevan.

Kiguradze, T., Sagona, A., 2003. On the origins of the Kura-Araks cultural complex. In: Smith, A., Rubinson, K.S. (Eds.), Archaeology in the Borderlands: Investigations in Caucasia and beyond. Cotsen Institute of Archaeology, Los Angeles, pp. 38-94.

Kingswood, S., Blank, D., 1996. Gazella subgutturosa. Mammalian Species 518, 1-10.
Klingel, H., 1977. Observations on social organization and behaviour of African and Asiatic wild asses (Equus africanus and E. hemionus). Z Tierpsychol 44 (3), 323-331.

Krueger, K., 2008. Social ecology of horse. In: Korb, J., Heinz, J. (Eds.), Ecology of Social Evolution. Springer-Verlag, Berlin-Heidelberg, pp. 195-206.

Legge, A.J., Rowley-Conwy, P.A., 2000. The exploitation of animals. In: Moore, A.M.T. Hillman, G.C., Legge, A.J. (Eds.), Village on the Euphrates. Oxford University Press, Oxford, pp. 423-471.

Lindsay, I., Smith, A.T., 2006. A History of archaeology in the republic of Armenia Journal of Field Archaeology 31 (2), 165-184.

Lubinski, P.M., 1999. The communal pronghorn hunt: a review of the ethnographic and archaeological evidence. Journal of California and Great Basin Anthropology 21 (2), 158-181.

MacDonald, M.C., 2005. Of rock-art, 'Desert kites' and Mesayid. In: Sedov, A.V. Smulyanskaya, I.M. (Eds.), Arabia Vitalis: Arabskij Vostok, Islam, Drevnyaya, Araviya: Sbornik Naychnykh Statej, Posvyashchennyj 60-letiyu V.V. Naumkina. Rossijskaya Akademiya Nauk, Moscow, pp. 332-345.

Mallon, D.P., 2008. Gazella subgutturosa. The IUCN Red List of Threatened Species Version 2014.3. www.iucnredlist.org. Downloaded on 13 March 2014.

Mallon, D.P. Kingswood, S.C. 2001. Antelopes. Part 4: North Africa, the Middle East, and Asia. Global Survey and Regional Action Plans, vol. viii. SSC Antelope Specialist Group.IUCN, Gland and Cambridge, p. 260.

Manaseryan, N., 2003. Hunting tackle, animals and objects in rock engravings from Armenia. Archaeofauna 12, 193-201.

Martin, L., 2000. Gazelle (Gazella sp.) behavioural ecology: predicting animal behaviour for prehistoric environments in southwest Asia. Journal of Zoology 250, 13-30.

Martirosyan, A.A., Israelyan, A.R., 1971. Rock Carvings in Gegham Mountains. Issue 2. Publishing house of Academy Sciences of Armenia, Yerevan.

Martirosyan-Olshansky, K., Areshian, G.E., Avetisyan, P., Hayrpetyan, A., 2013. Masis blur: a late neolithic settlement in the Plain of ararat, Armenia. In: Backdirt 2013: Annual Review of the Cotsen Institute of Archaeology at UCLA.

Mendelssohn, H., 1974. The development of the populations of gazelles in Israel and their behavioural adaptations, In: Geist, V. Walther, F. (Eds.), The Behaviour of Ungulates and its Relation to Management. IUCN, Morges, Switzerland.

Meshveliani, T., Bar-Oz, G., Bar-Yosef, O., Belfer-Cohen, A., Boaretto, E., Jakeli, N., Koridze, I., Matskevich, Z., 2007. Mesolithic hunters at Kotias Klde, western Georgia: preliminary results. Paléorient 33, 47-58.

Meshveliani, T., Bar-Yosef, O., Belfer-Cohen, A., 2004. The upper paleolithic in western Georgia. In: Brantingham, P.J., Kuhn, S.L., Kerry, K.W. (Eds.), The Early Upper Paleolithic beyond Western Europe. University of California Press, Berkeley, pp. 129-143.

Mezhlumyan, S.K., 1972. Paleofauna Epokh Eneolita, Bronzy I Zheleza Na Teritorii Armenii. Izdatel'stvo AN Armyanskoi SSR, Yerevan.

Mirzoyan, L., Manaseryan, N., 2009. Archaeozoological investigation of the site of shirakavan, 3rd - 1st millennia B.C., Armenia. In: Vila, E., Gourichon, L. (Eds.), Proceedings of the Eighth International Symposium on the Archaeozoology of Southwestern Asia and Adjacent Areas, Travaux de la maison de l'Orient, Lyon, pp. 500-511.

Mirzoyan, L., Manaseryan, N., 2010. Animal impact on the economic, religious and cultural aspects of the life of Urartians. In: 11th ICAZ Conference Paris August 2010. www.bonecommons.com (accessed 13.11.14.).

Mkrtumyan, Y.I., 1974. Les formes d'élevage en Arménie orientale (in Russian). Ethnography and Folklore of Armenia 6, 7-92.

Monahan, B., 2004. Faunal remains from the Tsakahovit Plain. In: Mezhdunarodnaya Nauchnaya Konferentsiya “Arkheologiya, Etnologiya, Fol'kloristika Kavkaza". Sbornik kratkikh soderzhanij dokladov, Tbilisi, pp. 99-100.

Montoya, C., Bălăšescu, A., Joannin, S., Ollivier, V., Liagre, J., Nahapetyan, S., Ghukasyan, R., Colonge, D., Gasparyan, B., Chataigner, C., 2013. The upper palaeolithic site of kalavan 1 (Armenia): an Epigravettian settlement in the lesser caucasus. Journal of Human Evolution. http://dx.doi.org/10.1016/j.jhevol. 2013.07.011.

Nadel, D., Bar-Oz, G., Avner, U., Malkinson, D., 2013. Ramparts instead of walls: building techniques of large game traps (kites) in the Negev Highland. Quaternary International 297, 147-154.

Nioradze, M., 2006. Le Paléolithique supérieur de la Géorgie (2001-2005). In: Noiret, P. (Ed.), Le Paléolithique Supérieur Européen Bilan Quinquennal 2001 2006. Actes du XVe Congrès UISPP, Lisbonne, 4-9 Septembre 2006. ERAUL 115 Liège, pp. 9-15.

Nioradze, M.G., Otte, M., 2000. Paléolithique supérieur de Géorgie. L'Anthropologie $104,265-300$.

Olçer, S.Y., 2001. Turkey. In: Mallon, D.P., Kingswood, S.C. (Eds.), Antelopes. Part 4 North Africa, the Middle East and Asia, Global Survey and Regional Action Plans. IUCN/SSC Antelope Specialist Group. IUCN, Gland and Cambridge, pp. $112-113$.

Outram, A.K., Stear, N.A., Bendrey, R., Olsen, S., Kasparov, A., Zaibert, V., Thorpe, N. Evershed, R.P., 2009. The Earliest horse Harnessing and Milking. Science 323, $1332-1335$.

Palumbi, G., 2003. Red-black pottery, eastern-Anatolian and Transcaucasian relationships around the mid-Fourth millennium B.C. Ancient Near Eastern Studies 40, 80-134.

Petrosyan, A., Ghukasyan, R., Colonge, D., Fourloubey, C., Arakelyan, D., Astruc, L., Mallon, D.P. Kingswood, S.C., 2001. Antelopes. Part 4: North Africa, the Middle East, and Asia. Global Survey and Regional Action Plans, vol. viii. SSC. Antelope Specialist Group. IUCN, Gland and Cambridge. 
Picalause, P., Cauwe, N., Lemaitre, S., Vander Linden, M., Van Berg, P.L., 2004 Desert-kites of the Hemma plateau (Hassake, Syria). Paléorient 30 (1), 89-99.

Piro, J.J., 2008. Pastoral economies in early Transcaucasian communities from the mid-IVth to IIIrd millennium B.C. In: Vila, E., Gourichon, L. (Eds.), Proceedings of the Eighth International Symposium on the Archaeozoology of Southwestern Asia and Adjacent Areas, Travaux de la maison de l'Orient, Lyon, pp. 433-446.

Pinhasi, R., Gasparian, B., Nahapetyan, S., Bar-Oz, G., Weissbrod, L., Bruch, A.A Hovsepyan, R., Wilkinson, K., 2011. Middle Palaeolithic human occupation of the high altitude region of Hovk-1, Armenia. Quaternary Science Reviews 30, 3846-3857.

Rosen, B., Perevolotsky, A., 1998. The function of "desert kites" - hunting or livestock husbandry? Paléorient 24, 107-111.

Sagona, A.G., 1993. Settlement and society in late prehistoric Trans-Caucasus. In: Frangipane, M. (Ed.), Between the Rivers and over the Mountains. University of Rome La Sapienza, Rome, pp. 453-474.

Sargsyan, 1988. Test Excavations at the Site of Dzori Berd. ARCYS VIII: Questions of Investigation of Armenian National Culture (Culture and Language), pp. 76-77 (in Armenian).

Smith, A., 2005. Prometheus unbound: southern Caucasia in prehistory. Journal of World Prehistory 19, 229-279.

Smith, A.T. Badalyan, R.S., Avetisyan, P., 2009. The archaeology and Geography of ancient Transcaucasian societies. In: The Foundations of Research and Regional Survey in the Tsaghkahovit Plain, Armenia, vol. I. Chicago.

Steward, J.H., 1943. Culture element distributions: XXIII, northern and Gosiute Shoshoni. In: Anthropological Records, vol. 8 (3). University of California, Berkeley.

Turan, N., 1984. Türkiye'nin Av Ve Yaban Hayvanları - Memeliler. Ar Yayınevi Ankara.
Uerpmann, H.-P., 1973. Animal bone finds and economic archaeology: a critical study of "osteoarchaeological" method. World Archaeology 4 (3), 307-322.

Vereshchagin, N.K., 1967. The Mammals of the Caucasus. A History of the Evolution of the Fauna (Jerusalem).

Vila, E., Balasescu, A., Radu, V., Badalyan, R., Chataigner, C., 2015. Neolithic subsistence economy in the plain of Ararat: preliminary comparative analysis of the faunal remains from Aratashen and Khaturnarkh-Aknashen (Armenia). In: Mashkour, M., Beech, M. (Eds.), Archaeozoology of the Near East 9. Oxbow Books (Spring 2015). Chapter 8: The Caucasian Zooarchaeology. http://www. oxbowbooks.com/oxbow/archaeozoology-of-the-near-east-9.html.

Warmuth, V., Eriksson, A., Bower, M.A., Barker, G., Barret, E., Hanks, B.K., Li, S., Lomitashvili, D., Ochir-Goryaeva, M., Sizonov, G.V., Soyonov, V., Manica, A., 2012. Reconstructing the origin and spread of horse domestication in the eurasian steppe. Proceedings of the National Academy of Sciences 109 (21), 8202-8206.

Wilkinson, K.N., Gasparian, B., Pinhasi, R., Avetisyan, P., Hovsepyan, R., Zardaryan, D., Areshian, G.E. Bar-Oz G. Smith, A, 2012. Areni-1 cave, Armenia: a chalcolithicEarly Bronze age settlement and ritual site in the southern Caucasus. Journal of Field Archaeology 37 (1), 20-33.

Williams, L., Zazanashvili, N., Sanadiradze, G., Kandaurov, A. (Eds.), 2006. Ecoregional Conservation Plan for the Caucasus. WWF, KFW, BMZ, CEPF, MacArthur Foundation. Signar Ltd.

Zazanashvili, N., Manvelyan, K., Askerov, E., Krever, V., Kalem, S., Avcioglu, B., Galstyan, S., Mnatsekanov, R., Bitsadze, M., 2009. Territorial protection of globally threatened species in the Caucasus. In: Zazanashvili, N., Mallon, D. (Eds.), Status and Protection of Globally Threatened Species in the Caucasus. CEPF, WWF. Contour Ltd, Tbilisi, pp. 222-231.

Zeder, M.A., Bar-Oz, G., Rufolo, S., Hole, F., 2013. New perspectives on the use of kites in mass-kills of Levantine gazelle: a view from northeastern Syria. Quaternary International 297, 110-125. 